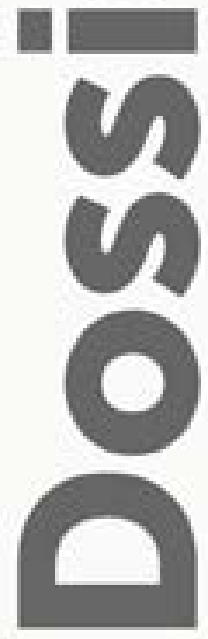

\title{
Eliminar "sem deixar vestígios": a distensão política e o desaparecimento forçado no Brasil
}

\author{
Eliminate "without leaving a trace": \\ political distension and enforced disappearance in \\ Brazil

\section{RESUMO}

Transcorridos mais de 30 anos desde a (re)democratização no Brasil, observam-se importantes lacunas nas articulações entre o passado e o presente, no que tange ao legado da ditadura militar. Com o objetivo de contribuir para o entendimento desse processo histórico, este texto procura caracterizar o desaparecimento forçado enquanto estratégia repressiva da ditadura e sua centralidade no processo de distensão política. Propomo-nos a traçar um panorama de seus antecedentes históricos e a prevalência de paralelos existentes nas estratégias repressivas dos governos dos generais Médici e Geisel. Este estudo beneficiou-se de documentos inéditos ou pouco explorados, e uma ampla revisão da bibliografia existente sobre o assunto, a fim de apresentar um balanço crítico sobre o aparato repressivo e o período imediatamente anterior à distensão política no país.

Palavras-chave: Ditadura militar - Desaparecimento forçado - Aparato repressivo - Distensão política - Redemocratização brasileira

\begin{abstract}
More than 30 years after the re-democratization in Brazil, considerable gaps loom large on the connections between the past and the present in terms of the legacy of the military dictatorship. In order to increase our understanding of such historical process, this article attempts to characterize enforced disappearances as a central repressive strategy of the dictatorship amidst the political distention process. Our aim is to provide an overview of the historical background regarding enforced disappearances, pointing out the parallels between the repressive strategies of Medici's and Geisel's military governments. This study stems from unpublished or little-explored documents and also from a broad review of the existing bibliography on the issue, therefore presenting a critical assessment of the repressive apparatus and the period immediately preceding the political distension in the country.
\end{abstract}

Keywords: Military dictatorship - Enforced disappearances - Repressive apparatus - Political distension - Brazil (re)democratization

* Doutora em História Social pela Universidade de São Paulo (USP). Professora de História do Brasil do curso de Graduação em História da Universidade Estadual de Minas Gerais (UEMG). Professora do Curso de Especialização "Direitos Humanos e Lutas Sociais" do Centro de Antropologia e Arqueologia Forense (CAAF) da Unifesp. CV: <http://lattes.cnpq.br/9006589887994222> 


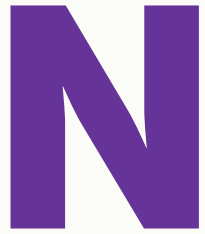

- Brasil, muitos acontecimentos relativos à ditadura militar ${ }^{1}$ permanecem desconhecidos, sobretudo no que diz respeito às vítimas fatais do regime. A despeito dos esforços empenhados pela Comissão Nacional da Verdade (CNV), ${ }^{2}$ observa-se a existência de importantes lacunas nas articulações entre o passado e o presente, no que tange ao legado da ditadura e à memória daqueles que a ela se opuseram ativamente. Com o objetivo de contribuir para o entendimento desse processo histórico, este artigo busca caracterizar o desaparecimento forçado ${ }^{3}$ enquanto estratégia repressiva da ditadura e sua centralidade no processo de distensão política.

Para tanto, propomo-nos a traçar um panorama dos antecedentes desse processo e das principais mudanças observadas nas estratégias repressivas do regime ditatorial, a fim de elucidar o desaparecimento forçado enquanto política de Estado no país. Uma análise mais detida sobre esta política sugere paralelos significativos entre os governos dos generais Médici e Geisel, em contraste com a análise tradicionalmente reportada pela historiografia. Desde essa perspectiva, analisaremos a atuação dos principais agentes políticos, pontuando as características mais significativas da dinâmica desse processo histórico, a fim de aprofundar nossa compreensão a respeito desse período.

Este estudo busca demonstrar o papel central desempenhado pelo "desaparecimento forçado" na promoção do projeto de distensão política, que levou em conta sua relevância operacional, assim como sua utilidade como meio eficaz de evitar maior desgaste ao governo. No início dos anos 1970, o custo político resultante da difusão de denúncias de violações dos direitos humanos e dos efeitos provenientes dos abalos iniciais do "milagre econômico" despontava no horizonte institucional da ditadura. Neste momento, o desaparecimento forçado se apresenta como um instrumento estratégico para amenizar os primeiros sinais de erosão da legitimidade dos militares, bem como para construir uma imagem de "moderado" para Geisel e os "castelistas", facilitando o diálogo com a "oposição responsável" e a impulsão do projeto de "descompressão política".

A presente análise retoma a crítica da "visão dualista" sobre os militares, tradicionalmente

1 Coincido com os autores Martins Filho (1995), Carlos Fico (2004) e Napolitano (2014), entre outros, que caracterizam a ditadura como predominantemente militar, tendo em vista que as FFAA detinham o controle dos principais centros de poder, sobretudo, o de definir a "sucessão presidencial" por meio do Alto Comando das Forças Armadas. Esta realidade se consolidou, a despeito do fato de o golpe de 1964 ter sido deflagrado desde um projeto político-econômico construído por uma aliança civil-militar, que beneficiou significativamente empresários brasileiros e multinacionais.

2 As Comissões da Verdade foram criadas, predominantemente, a partir dos anos 1980. Suas principais funções são apurar os fatos, apontar os agentes do Estado identificados como autores das violações de direitos humanos e indicar a responsabilidade a eles imputada. Outra função recorrente é a de inviabilizar a "negação continuada" por parte dos perpetradores dessas violações. As comissões, em geral, comprometem-se em reunir informações sobre as experiências das populações afetadas pela violência, sobretudo, estatal. Sem poderes de arbitrar penas, elas permitem abordar os problemas decorrentes dessas violações, sob regimes autoritários ou períodos de guerra, sem causar sérios abalos à ordem instituída, cf. Hayner (2014), p. 10-21. No Brasil, a CNV foi instalada em 2012 e o término de suas atividades ocorreu em 2014. cf. COMISSÃO NACIONAL DA VERDADE. Relatório da Comissão Nacional da Verdade. Brasília/DF, 2014. 3 v., p. 17-49 (doravante, será mencionada aqui apenas como CNV, seguida do ano). Sobre a CNV, ver Westhrop et. al. (2016) e Quinalha e Teles (2020), entre outros.

3 Segundo o direito internacional dos direitos humanos, o desaparecimento forçado ocorre a partir da privação de liberdade, seguida da recusa do Estado em informar o destino da pessoa. Este crime tem caráter permanente e não cessa enquanto seu paradeiro não é conhecido, cf. CNV (2014), p. 292-96. No Brasil, essa concepção difere daquela considerada pelos familiares ao longo do período ditatorial, segundo a qual o desaparecido era aquele sobre o qual não havia confirmação oficial da morte, ainda que seu corpo fosse localizado, cf. Almeida et al. (2009). Para o direito internacional, a ocultação do cadáver é o componente decisivo para a definição de "desaparecimento forçado", independentemente da confirmação oficial da morte. 
classificados entre "duros" e "moderados"4 ao longo do período ditatorial, elaborada por João Roberto Martins Filho (1995), ${ }^{5}$ aprofundando-a a partir das evidências mais recentes disponíveis. Os indícios revelados pelo "Dossiê Ditadura: os Mortos e Desaparecidos Políticos no Brasil 1964-1985" (Almeida et al., 2009) ${ }^{6}$ e o relatório da Comissão Nacional da Verdade7, entre outras obras, sugerem que as FFAA apresentaram uma notável unidade no plano estratégico, situando suas tensões e divergências no campo das opções táticas. Essas evidências reforçam a hipótese de que a autoimagem, construída pelos "castelistas", como um grupo "moderado" não coincide com os dados empíricos disponíveis na atualidade.

Para tanto, este texto beneficiou-se de documentos inéditos ou pouco explorados, e uma ampla revisão da bibliografia existente sobre o assunto, que propiciaram a produção de balanços críticos sobre o aparato repressivo, o período imediatamente anterior à distensão política, bem como sobre a fase que inaugura o início da transição democrática no Brasil. Por fim, é de se considerar que este texto faz parte de um estudo mais amplo em desenvolvimento, sobre a ditadura militar e seu legado, desde a perspectiva das investigações produzidas pela CNV e suas repercussões.

\section{A reorganização do Estado e do aparato repressivo após o golpe de 1964}

O golpe civil-militar de 1964 desencadeou uma onda repressiva dirigida a membros do governo deposto, bem como às lideranças sindicais, militares e comunistas comprometidas com João Goulart. Estima-se que, somente nos primeiros meses após o golpe, entre 30 e 50 mil pessoas tenham sido presas. ${ }^{8}$ Entre 1964 e 1965 ocorreram ao menos 810 intervenções sindicais no país. Paralelamente, as Ligas Camponesas foram destruídas e a maioria dos sindicatos rurais, organizados entre 1963 e 1964, foi extinta. A estrutura sindical rural foi reestruturada e submetida à CLT, ficando sob o controle do Ministério do Trabalho (Alves, 1984).

Ao longo da "Operação Limpeza" organizada a fim de "sanear" o país de uma suposta ameaça comunista, iniciada após o golpe de Estado, o poder legislativo e os partidos políticos foram alvos de perseguição. A despeito da colaboração do Congresso Nacional com a iniciativa golpista, os expurgos conduziram à cassação de 40 deputados federais, somente no ano de 1964 (Azevedo e Rabat, 2012, p. 28-31, 99, 197-201). Na burocracia civil e militar, esses expurgos funcionaram como um valioso elemento de dissuasão da contestação, sendo que os mais drásticos se deram na burocracia estatal diretamente vinculada às políticas econômica e social do governo de João Goulart (Alves, 1984).

\footnotetext{
4 Essa "visão dualista" está presente nas obras de Alves (1984); D’Araújo et al. (1994a; 1994b), Huggins (1998) e (Fico, 2001, p. 56), entre outros. Carlos Fico ressalta a complexidade e os matizes existentes entre diversos grupos militares, mas emprega a divisão entre "duros" e "moderados" (Ib., p.41)

5 A crítica de Martins Filho (1995, p. 115-120) diz respeito ao período transcorrido entre 1964 e 1969, no qual se digladiaram ao menos 4 grupos militares. Em seu livro mais recente (Martins Filho, 2019), examina os anos de 1969 a 1976, empregando predominantemente as 2 categorias tradicionais.

6 Uma versão anterior dessa obra serviu de base para o desenvolvimento das atividades da Comissão Especial de Mortos e Desaparecidos Políticos (CMDP), a partir de 1996.

7 CNV (2014).

8 Cf. dados disponíveis em Alves (1984, p. 59), Huggins (1998, p. 142), Sá Motta (2014, p. 26).
} 
Em pouco tempo, o marechal Castelo Branco editou o Al-2 (1965) e o Al-3 (1966), impondo o bipartidarismo, as eleições indiretas para governador e prefeitos em cidades consideradas estratégicas para a Segurança Nacional e a instalação de um intrincado sistema eleitoral controlado, estendendo ainda a abrangência da Justiça Militar (JM) aos civis processados pela Lei de Segurança Nacional (LSN). Antes de deixar o governo, ele promulgou a Constituição Federal (1967), adotando a noção de "inimigo interno", segundo a qual todo cidadão é responsável pela segurança nacional, decretou a nova LSN, a Lei 317 (a Lei Orgânica da Polícia), ${ }^{9}$ e a Lei de Imprensa, lançando as bases institucionais da ditadura. ${ }^{10}$ Castelo Branco estabeleceu o avanço da militarização do Estado de Segurança Nacional (implantada por decretos-leis), por meio da Reforma Administrativa e da criação do Alto Comando das Forças Armadas, o qual assumiria funções autônomas nos momentos mais críticos do regime, sobretudo na crise sucessória de 1969 (Martins Filho, 1995, p. 94).

A constante preocupação da ditadura militar em manter a base social que viabilizou o golpe de Estado fez com que o regime, inicialmente, evitasse desencadear uma repressão mais ampla, permitindo a determinados setores certa liberdade de expressão. O governo necessitava manter algum respaldo civil, utilizando-se de instrumentos de controle que combinavam o uso da força ao lado da persuasão e cooptação.

A ditadura brasileira caracterizou-se pela utilização de estratégias repressivas seletivas, cujas práticas oscilaram entre esconder e mostrar a violência estatal, combinando a intenção do regime de se legitimar com a necessidade de difundir o medo. Segundo esta perspectiva, foi produzida uma extensa legislação de exceção e uma ampla estrutura administrativoinstitucional, que possuía relativa eficiência, na qual se combinaram leis anteriores ao golpe e novos atos legislativos. Essa legislação passou a dar um "significado jurídico a uma esfera de ação em si extrajurídica" (Agamben, 2004a, p. 24), própria do estado de exceção, no qual a suspensão da ordem jurídica é sua condição extrema. Com efeito, a ditadura soube transitar com certa habilidade na zona de indistinção entre o legal e a situação de fato, entre o que estava "dentro e fora" do ordenamento jurídico (Agamben, 2004b, p. 177).

A manutenção de uma esfera pública que conservava alguns dispositivos democráticos dava uma aparência de normalidade e legitimidade ao regime, desde a manutenção do Congresso Nacional (bastante controlado), de um partido de oposição moderada e de um sistema judiciário, a despeito de seu perfil "de exceção". ${ }^{11} \mathrm{~A}$ implementação desse sistema exigiu a estruturação de um aparelho burocrático de Estado sofisticado e altos níveis de colaboração entre civis e militares. Esta estruturação possibilitou a divisão de responsabilidades e certa margem para administrar o poder e as disputas dentro e fora do aparato estatal (Teles, 2011).

9 Esta lei submeteu as polícias civil e militar ao Secretário Estadual de Segurança Pública, então indicado pelos militares. Note-se que a Seção de Segurança Pública (OPS), ao lado da Agência Central de Inteligência (CIA), colaborou na implementação da lei e forneceu treinamento às polícias brasileiras, pois considerava importante sua atuação coordenada no combate à subversão e controle da sociedade. A lei destinava-se a reduzir o conflito e eliminar a competição entre as duas forças policiais (Huggins, 1998, p. 126-35, 151-57).

10 Em fevereiro de 1967, instalam-se as Divisões de Segurança e Informações (DSI) nos ministérios civis, promovendo o espraiamento do braço repressivo sobre a administração pública (art. 29, D-L 200, de 25/02/67). Disponível em: <https:// legislacao.presidencia gov $\mathrm{br} /$ atos/?tipo =DEL \&numero=2008ano=1967\&ato=087ATRa50MZRVTfce>. Acesso em: $20 \mathrm{mar}$. 2020. As DSI eram fonte de tensões, pois estavam subordinadas ao respectivo ministro e, simultaneamente, ao SNI (Fico, 2001, p. 83-4).

${ }^{11}$ Arquidiocese de São Paulo. Brasil: Nunca Mais - um relato para a história. Petrópolis/ RJ: Vozes, 1989. 312 p. 
Nesse contexto, o aparato repressivo evoluiu gradativamente para uma atuação mais violenta e centralizada, mediante a reorganização do Estado, que levou as Forças Armadas à coordenação e assunção do papel de polícia política. Essa centralização favoreceu a opção pelo extermínio de lideranças políticas e de quadros da luta armada, refletindo a aplicação eficiente da repressão clandestina e ilegal, em associação com a atuação legitimada pelas leis de exceção.

A partir de maio de 1967, mudanças significativas tiveram lugar em decorrência da reorganização dos órgãos de informação das Forças Armadas, transformados em "organismos mistos", que combinavam operações de informação e de repressão (Fico, 2001, p. 63, 912). O acirramento dos conflitos com as esquerdas e grupos de oposição e das disputas pela sucessão presidencial no interior do governo (Martins Filho, 1995, p. 146-154) aceleraram o processo no qual o Exército assumiu o comando das atividades de segurança pública e da segurança interna, a partir, sobretudo, da edição do Al-5.

A reorganização do aparato repressivo brasileiro revela a influência da doutrina francesa da guerra revolucionária. Essas ideias chegaram ao país em 1959, por meio da Escola Superior de Guerra (ESG), antes de serem adotadas pelas escolas militares dos EUA em 1961, consolidando a justificativa do emprego sistemático da tortura como "instrumento legítimo" de combate à "subversão". O anticomunismo comum aos militares dos dois países contribuiu para a crescente influência dos ensinamentos franceses, destinados a enfrentar o novo tipo de guerra não convencional, que combinava política, ideologia e operações militares. O contexto da "Guerra Fria" exigia a constituição de uma organização de defesa interna capaz de unificar a atuação das forças policiais e militares, combinando atividades de informação e operação em um mesmo órgão, tal como fez o governo francês na Argélia, ao criar os Destacamentos Operacionais de Proteção (DOP), que inspiraram seus congêneres brasileiros. ${ }^{12}$

Em linha com essa perspectiva, em maio de 1967, a Seção de Segurança Pública (OPS) da USAID ${ }^{13}$ avaliou positivamente o auxílio às polícias brasileiras na formação de serviços especiais, tais como "tropas de choque" de tipo militar, para o combate das ameaças à segurança interna, alcançando bons resultados na repressão às manifestações estudantis, assim como no controle das favelas do Rio de Janeiro. ${ }^{14}$ No mesmo ano, o Centro de Informação do Exército (CIE) enviou agentes para realizar cursos de controle insurrecional nos EUA e na Grã-Bretanha, a fim de aperfeiçoar seus conhecimentos relativos à "guerra interna". ${ }^{15}$

O contexto de escalada da inquietação social, envolvendo movimentos de rua e greves operárias, e das ações armadas de grupos de esquerda, ao longo do primeiro semestre de 1968,

12 (Martins Filho, 2019, p. 180-85, 194). O general Paul Ausserresse, ativo na repressão à Guerra de Independência da Argélia, ministrou cursos nos EUA, entre 1961 e1963, e no Centro de Instrução de Guerra na Selva (CIGS), de Manaus, para militares da América Latina, entre 1973 e 1975. Segundo o general Manuel Contreras, chefe da Direção Nacional de Inteligência (DINA), o envio de oficiais chilenos ao Brasil era realizado a cada dois meses. O treinamento ocorria na Escola Nacional de Informações (ESNI), em Brasília, e era complementado em Manaus (Robin, 2004, p. 364-66, 384).

13 Os treinamentos de policiais brasileiros por meio da OPS, com apoio da CIA, foram intensificados a partir de 1964, combinando cursos de informação e "guerra de guerrilha" com o aperfeiçoamento em segurança pública (Huggins, 1998, p. 135, 143-63).

14 Em 1966, a OPS enviou Dan Mitrione ao Brasil como consultor, a fim de criar uma unidade de choque na PM do Rio de Janeiro. Ele ensinava espionagem, contraespionagem e "sobrevivência na selva", sua orientação era de "atirar para matar" à noite, como os franceses fizeram na Argélia (Huggins, 1998, p. 156-63).

15 (Huggins, 1998, p. 158). Neste período, a política britânica para o Brasil se voltava para os laços comerciais, sobretudo militares, que tinham prioridade sobre pruridos relativos ao caráter autoritário da ditadura (Martins Filho, 2019, p. 24-25, 26-39). 
conduziu à intensificação da organização de serviços especiais de combate à "subversão". Note-se que a edição do Ato Institucional no. 5 (Al-5) ocorreu em um momento no qual as grandes manifestações de rua estavam em declínio, configurando-se mais como um elemento decisivo na disputa sucessória à presidência da República, que conturbava o cenário políticoinstitucional, na qual se enfrentaram quatro grupos militares, conforme análise de Martins Filho. ${ }^{16}$

Em consonância com essas transformações do aparato repressivo, a Operação Bandeirante (OBAN) foi inaugurada em julho de $1969,{ }^{17}$ com financiamento de empresários, banqueiros e multinacionais. ${ }^{18}$ Desde a experiência bem-sucedida da OBAN, um ano depois, criou-se o sistema DOI-Codi (Destacamentos de Operações de Informações - Centros de Operações de Defesa Interna). Gradualmente, este sistema passou a ser composto de uma rede de unidades secretas e clandestinas especializada no combate à "guerra revolucionária".

O DOI-Codi constituiu o principal palco da desumanização e despersonalização dos prisioneiros políticos. Ali, agentes do Estado operaram no limiar das leis de exceção, escorados na Lei de Segurança nacional (LSN 898/69). As brechas legais, exterioridades jurídicas não passiveis de criminalização (Al-5, @ 11), abriram a possibilidade para todo tipo de práticas clandestinas dos órgãos repressivos, em especial, a utilização da tortura - não legalizada pela legislação de exceção, mas permitida em função da generalização da mencionada zona de indistinção e da expressiva ampliação do poder do Executivo.

Aliadas a essa complexa estrutura, estavam o uso da censura e de uma sofisticada propaganda política (Fico, 1997), que atuou agressivamente sob a atmosfera de aparente legalidade. Sob esta lógica, órgãos de informação foram criados por meio de leis, decretos e outros diplomas ostensivos, enquanto os $\mathrm{DOI}$-Codi tiveram origem em diretrizes secretas do Conselho de Segurança Nacional e de autoridades designadas pela presidência da República (Fico, 2004, p. 82).

A face mais visível da repressão, contudo, era composta pelos Departamentos Estaduais de Ordem Política e Social (DOPS), existentes desde 1924; pela Justiça Militar; os Institutos Médico Legal (IML); cemitérios públicos e os presídios. O sistema carcerário foi reutilizado para punir, separar e isolar os dissidentes. Esta estrutura permitiu o uso sistemático de valas clandestinas em cemitérios públicos de São Paulo, Rio de Janeiro e Pernambuco, o que afastou a hipótese de que essas práticas resultariam de "excessos" estranhos ao padrão de conduta das instituições e autoridades brasileiras (CNV, 2014, vol. I, p. 844-46).

A JM estava assentada em diversos atos legislativos, que se sobrepunham e se confundiam. Gradativamente, a legalidade de exceção se transformou em um sistema inchado, no qual se sobrepunham, além da Constituição, mais de 366 atos legislativos distintos, entre

16 Segundo Martins Filho (1995, p. 146-154), os "castelistas" formularam o Al-5 com os "palacianos" em meados de 1968. Os "duros" ou "costistas" e os "albuquerquistas" compõem o conjunto de grupos em disputa. Os "duros" foram os últimos a concordar com a edição do Al-5, tendo em vista que essas alianças estavam interligadas às disputas pela sucessão presidencial.

17 Paralelamente, em julho de 1969, o CIE iniciou operações de informação no Pará, Goiás e Maranhão, a fim de localizar os militantes do PC do B, que viriam a enfrentar a repressão à "Guerrilha do Araguaia", a partir de 1972 (CNV, 2014).

18 Desde a deserção do capitão Lamarca e o roubo das armas do regimento de Osasco (SP), em janeiro de 1969, organizada pela VPR, o II Exército estruturou o serviço secreto (E2), responsável pela segurança interna da grande São Paulo. Formou-se, então, um grupo especializado composto por efetivos da Secretaria Pública de São Paulo, do DOPS, CIE, o Centro de Informações da Aeronáutica (CISA) e do II Exército, a fim de combater a luta armada (Joffily, 2008, p. 40). 
atos excepcionais, leis e atos complementares e ordinários. ${ }^{19} \mathrm{~A} \mathrm{JM}$, assim como a legalidade de exceção, se tornou elementos fundamentais para a legitimação do regime e importantes fatores da desmobilização da contestação política.

Os dados indicam a seletividade empreendida na repressão judicial. Na JM, das 17.420 pessoas submetidas aos inquéritos policiais com base na LSN, apenas $42 \%$ foram acusadas judicialmente (Teles, 2011). A quantidade de vítimas fatais da repressão extrajudicial também estabeleceu um padrão seletivo - ao menos 434 pessoas foram mortas ou desapareceram expressamente por motivos políticos durante a ditadura (CNV, 2014).20

Paralelamente, a violência policial se aprofundou, sobretudo a partir do fato que a Polícia Militar (PM) tenha se tornado uma força auxiliar e de reserva do Exército, em julho de 1969, estabelecendo amplo controle sobre o Estado e a sociedade. Assiste-se a um "espraiamento" ideológico e institucional dos militares no aparato estatal: as PM assumiram funções não apenas no policiamento ostensivo, mas também na guarda interna e administração de instituições totais e órgãos públicos. ${ }^{21}$ Nesse contexto de aperfeiçoamento das polícias e dos "Esquadrões da Morte" (Huggins, 1998), a repressão se estendeu sobre diversos grupos sociais, notadamente as favelas ${ }^{22}$. Centenas de camponeses e indígenas foram assassinados ou desapareceram em meio às disputas pela propriedade da terra no país. Estima-se que ao menos 1.196 camponeses e 8.350 indígenas (envolvendo 10 nações dos povos originários) morreram vítimas da ação, direta ou indireta, do Estado brasileiro nesse período. ${ }^{23}$

Em 1971, com a adoção do sistema DOI-Codi e a centralização do aparato repressivo consolidada, observa-se o início de uma mudança estratégica nos métodos de atuação da ditadura. Até então, a tendência do aparato repressivo era o assassinato de dissidentes sob tortura, cujos óbitos eram divulgados como mortes em tiroteios, atropelamentos ou suicídios, os quais eram enterrados como indigentes com nomes e causa mortis falsos em cemitérios públicos.

A partir de 1974, esta tendência é suplantada pelos "desaparecimentos forçados", que por sua natureza não precisavam ser "explicados" pelo governo, tal como mais adiante

19 SECRETARIA de Direitos Humanos. Habeas Corpus: que se apresente o corpo. A busca dos desaparecidos políticos no Brasil. Brasília/DF: SDH, 2010. 346 p., p.9

20 Compilei 435 casos, cf. dados de Almeida et al. (2009); CNV (2014); COMISSÃO da Verdade do Estado de São Paulo "Rubens Paiva". Relatório da CEV Rubens Paiva. São Paulo: Assembleia Legislativa, 2015. 90 p. Disponível em: <http://comissaodaverdade. al.sp.gov.br/relatorio/Introducao.pdf>. Acesso em: 20 fev. 2020; (doravante CEV-SP (2015)) e Comissão da Verdade da PUC-SP "Reitora Nadir Gouvêa Kfouri" (CVPUC). A CVPUC mencionou 5 mortos e desaparecidos, já conhecidos, que estudavam na PUC. Em 2019, porém, encontrou informações sobre um estudante desaparecido, que não consta de seu relatório final de 2017. Seu nome é João Maria Ximenes de Andrade, militante do PCB. Cf. "Família de aluno desaparecido durante a ditadura recebe diploma da PUC-SP". Disponível em: <https://i.pucsp.br/noticia/familia-de-aluno-desaparecido-durante-ditadura-recebediploma-da-puc-sp>. Acesso em: 20 fev. 2020.

${ }^{21}$ A PM acumulou funções de "segurança interna" e "segurança pública". Suas atribuições abrangiam desde o combate à luta armada até o policiamento ostensivo armado, preventivo e repressivo, cf. o D-L 667/69 (Teixeira, 2012, p. 100). Essa diretriz, bem como a que orientava pela integração das forças repressivas de segurança interna (resultando na OBAN), partiram do Seminário de Segurança Interna, realizado em Brasília no mês de fevereiro de 1969 (Fon, 1979; Huggins, 1998, p. 176-77).

22 COMISSÃO Estadual da Verdade do Rio de Janeiro. Relatório da Comissão da Verdade do Rio. Rio de Janeiro: CEV/RJ, 2015, p. 116-124.

${ }^{23}$ Paradoxalmente, a CNV não levou a termo a investigação a respeito da responsabilidade direta do Estado nos crimes cometidos contra indígenas e camponeses, publicando os dados disponíveis no Volume II de seu relatório, sem contabilizá-los em números oficiais (CNV, 2014, vol. II, p. 205). 
se tornaria prática corrente na Argentina ${ }^{24}$. Naquele momento, não interessava divulgar a existência de guerrilhas, tanto para evitar o "efeito multiplicador da propaganda" 25 quanto para diminuir a repercussão das denúncias de violações de direitos humanos no país e no exterior. Esse processo ganhou força no combate à Guerrilha do Araguaia e culminou em 1974, com o início o governo do general Ernesto Geisel (1974-1979). Em agosto daquele ano, Geisel inicia a fase de distensão política "lenta, gradual e segura", atraindo para si o status de "moderado" (Teles, 2005, p.230).

Nesse sentido, é possivel afirmar, retomando a noção de Pilar Calveiro de que a ditadura argentina representou um "poder desaparecedor", assim como que a repressão brasileira durante a ditadura constituiu um "poder torturador" (Teles, 2013, p. 8-14). ${ }^{26}$ Não obstante a prevalência do uso da tortura como estratégia repressiva no Brasil, nesse contexto mais amplo de mudanças de rota, no qual os estrategistas do governo delineavam um projeto de institucionalização da ditadura, é que se insere a guinada em direção à consolidação de uma política repressiva de "desaparecimento forçado".

Cabe lembrar que parte considerável da bibliografia concorda quanto ao fato de que os militares tenham iniciado o processo de "distensão política", considerando-se as pressões exercidas pela "sociedade civil" e pela conjuntura econômica (Codato, 2005, p. 83). A historiografia não coincide, porém, quanto à periodização desse processo, assim como não costuma abordar a articulação existente entre a distensão e as mudanças de rota da estratégia repressiva do governo. Ademais, a percepção hegemônica na literatura especializada, de que a repressão era frequentemente pautada pelas disputas entre militares "duros" e "moderados", tende a obscurecer nossa compreensão a respeito do desenvolvimento e da dinâmica desse processo.

Novas fontes e abordagens sugerem que o início dessas mudanças estava diretamente relacionado com o surgimento dos primeiros sinais da crise de legitimidade da ditadura. Neste período despontavam os indicadores iniciais de esgotamento do "milagre econômico", bem como se ampliavam os custos políticos decorrentes da divulgação das denúncias de violações de direitos humanos. Esses elementos consistiram fatores decisivos para o desenvolvimento do projeto de descompressão política gradualista, processo caracterizado pela prevalência da hierarquia militar na condução do aparato repressivo, conforme será apresentado nas próximas seções.

\section{A erosão de legitimidade}

\section{As denúncias de abusos aos direitos humanos no país e no exterior}

\footnotetext{
${ }^{24}$ Note-se que os prisioneiros políticos denunciaram a escalada de casos de desaparecimentos forçados a partir de 1973, no documento produzido em 1975, conhecido como "Bagulhão". Cf. COMITÊ PRÓ-ANISTIA GERAL DOS PRESOS POLITICOS NO BRASIL. Dos presos políticos brasileiros. Acerca da repressão fascista no Brasil. Lisboa: Ed. Maria da Fonte, 1976. 227 p., p. 160 -4.

${ }^{25}$ Cf. declaração do coronel Jarbas Passarinho (Dória et al., 1978, p. 23-4). Apenas em 1993, as FFAA reconheceram oficialmente a existência da Guerrilha do Araguaia, cf. Teles (2005).

${ }^{26} \mathrm{Na}$ Argentina, a partir de 1976, a figura do desaparecido deixou de ser uma das formas de repressão para se converter na modalidade repressiva do poder, cf. Calveiro (2013, p. 41).
} 
As campanhas de denúncia de abusos aos direitos humanos no Brasil e no exterior desempenharam um papel crucial na resistência à ditadura e, neste contexto, as campanhas organizadas por familiares de mortos e desaparecidos, e os presos políticos ocuparam um lugar de destaque.

Em âmbito nacional, o Conselho de Defesa dos Direitos da Pessoa Humana (CDDPH), criado por João Goulart em 1964, tornou-se um espaço de reivindicação de apuração de denúncias, a partir de sua viabilização funcional em 1968, decorrente das pressões institucionais da Ordem dos Advogados do Brasil (OAB) e da conjuntura caracterizada por protestos populares que tomaram conta do país.

Um dos casos que ganharam maior repercussão foi o de Olavo Hanssen, militante trotskista e líder sindical preso em 1 de maio de 1970, assassinado sob tortura no DEOPS/SP. O CDDPH foi acionado para analisar este caso, devido à pressão de sindicatos brasileiros e estrangeiros, de setores progressistas da Igreja Católica, intelectuais e estudantes, chegando ao Congresso Nacional. Não obstante, a investigação iniciada no conselho concluiu tratar-se de suicídio, em conformidade com a versão das autoridades, frustrando a sociedade civil e os congressistas de oposição.

No primeiro semestre de 1971, alguns casos de desaparecimento forçado alcançaram repercussão significativa, tais como os do deputado federal cassado Rubens B. Paiva e de Stuart Angel Jones, filho da famosa estilista Zuzu Angel (que seria assassinada pela ditadura em 1976). Embora denunciados no CDDPH, os casos foram arquivados. O governo Médici modificou a composição do conselho e estabeleceu que suas reuniões fossem secretas, de modo a garantir a maioria e o apoio às diretrizes do regime. Em março de 1972, o MDB se retirou do Conselho, alegando que ali não se apuravam as denúncias, e que a permanência de sua representação legitimava a ditadura. $A \mathrm{OAB}$, contudo, manteve-se no CDDPH, apesar de sua notória inoperância. ${ }^{27}$

A partir de 1973, alguns assassinatos de dissidentes galvanizaram a indignação da opinião pública e as missas celebradas em sua homenagem se transformaram em atos de protesto contra a violência ditatorial. As missas da Catedral da Sé, oficiadas pelo arcebispo de São Paulo D. Paulo E. Arns, ganharam relevância, tal como se verificou na homenagem realizada em março de 1973 para lembrar o estudante da USP, Alexandre Vannucchi Leme, assassinado sob tortura no DOI-Codi/SP no dia 17 daquele mês. A missa contou com a presença de Sérgio Ricardo - que interpretou a canção "Calabouço", composta em homenagem ao estudante Edson Luís, assassinado em 1968 - e de cerca de três mil pessoas, apesar da intensa repressão policial (Almeida et al., 2009, p. 427-31).

A reação provocada pela morte de Vannucchi Leme contribuiu para a reorganização do movimento estudantil em São Paulo, mobilizando setores da sociedade civil e ocupando espaços institucionais antes sufocados. Esses protestos ajudaram a fortalecer as redes de solidariedade aos perseguidos políticos que, gradativamente, ganharam visibilidade. Ela

27 Todos os casos apresentados ao CDDPH foram arquivados, cf. Teles (2005, p. 88-95, 105-12). 
preparou o terreno para as missas emblemáticas do jornalista Vladimir Herzog, em outubro de 1975, e a de Santo Dias da Silva, líder operário assassinado em novembro de 1979.

No plano internacional, no início de 1970, o senador democrata Frank Church iniciou uma investigação sobre "Políticas e Programas dos EUA no Brasil", em uma subcomissão da Comissão de Relações Exteriores do Senado norteamericano. A partir de denúncias de prisioneiros políticos brasileiros, reuniu um dossiê consistente sobre as violações aos direitos humanos perpetrados pelos órgãos de segurança ou esquadrões da morte. Em maio de 1971, o senador Church realizou audiências a portas fechadas, tendo em vista que elas abordavam questões sensíveis de inteligência. Embora Church tenha pressionado o chefe do programa de segurança pública da USAID, Theodore D. Brown, e o diretor da CIA, Richard Helms, ambos se esquivaram das responsabilidades pelo envolvimento direto na prática de tortura no Brasil (Green, 2009, p. 317-333).

Naquele período, o programa da USAID para o Brasil era o terceiro maior programa de assistência externa, depois do apoio dispensado ao Vietnã do Sul e à Índia. O senador inquiriu o diretor da USAID Brasil, William A. Ellis, para saber os motivos que levaram os EUA a conceder uma ajuda econômica no valor de 2,1 bilhões de dólares entre 1962 e 1970. Ellis respondeu que o estímulo ao desenvolvimento econômico promoveu a estabilidade política do país, o que convinha aos interesses de segurança dos EUA (Green, 2009, p. 333-34).

Em julho de 1971, o senador publicou o relatório sobre a investigação acerca dos programas de assistência econômica e militar ao Brasil, concluindo que estes contribuíram para o fortalecimento da ditadura militar e o recrudescimento das práticas policiais no país. Nesse mesmo ano, o programa foi drasticamente reduzido no Brasil e concluído em 1972. A publicidade negativa a respeito dos direitos humanos no país levou o Senado dos EUA a examinar as operações da OPS em outros países. A iniciativa do senador Church se transformou no início da conclusão dos programas de treinamento de polícias estrangeiras ${ }^{28}$, intimidando os militares brasileiros.

No âmbito da Organização dos Estados Americanos (OEA) destacaram-se dois casos, relativos a graves violações aos direitos humanos, que levaram a Comissão Interamericana de Defesa de Direitos Humanos (CIDH) a recomendar investigações, assinalando a responsabilidade do Estado brasileiro nas referidas violações. Em junho de 1970, a CIDH da OEA recebeu uma petição da Confederación Latino-Americana Sindical Cristiana e de outras organizações sindicais para investigar a morte de Olavo Hanssen. Com efeito, a $\mathrm{CIDH}$ era uma das poucas possibilidades que restavam àqueles que tentavam organizar campanhas de denúncias contra a ditadura brasileira (Green, 2009, p. 277, 286; Teles, 2005, p. 107).

Essas petições faziam parte desse contexto mais amplo de divulgação das denúncias de tortura no Brasil, que ganharam repercussão internacional entre 1969 e 1971, graças às campanhas encabeçadas por exilados, banidos e ativistas de direitos humanos. No período

\footnotetext{
${ }^{28}$ Em 1971, o deputado Ron Dellums propôs uma emenda à lei de Assistência Externa, condicionando a ajuda ao Brasil ao fim do uso da tortura como instrumento político, sem sucesso. O senador John Tunney tentou aprovar uma emenda semelhante, mas não conseguiu. Em 1972, nova tentativa se frustrou. Após o golpe no Chile, audiências realizadas na Câmara abordaram a questão. Apenas em 1975 foi aprovada uma legislação impedindo ajuda econômica a países que cometessem graves violações aos direitos humanos (Green, 2009, p. 330-43; Huggins, 1998, p. 218-225).
} 
entre 1970 e 1975, a CIDH tramitou entre 19 a 21 casos de denúncias envolvendo assassinatos e desaparecimentos forçados no Brasil, de um conjunto de 77 petições enviadas à Comissão. ${ }^{29}$ Essas pressões, porém, não garantiram condenações, pois somente os casos de Hanssen (caso 1683) e o que envolve o assassinato do assessor de D. Helder Câmara, padre Henrique, em Recife, no ano 1969 (caso 1684), obtiveram recomendações publicadas. Note-se que o caso 1684 foi iniciado após o recebimento de três denúncias anônimas, nas quais se afirmava a existência de 12 mil prisioneiros políticos, bem como o uso da prática sistemática de tortura no Brasil.

Com efeito, no relatório anual de 1973 da CIDH foi registrada a censura ao governo brasileiro por sua falta de colaboração com as investigações relativas aos dois casos, tendo em vista que o governo brasileiro não autorizou visitas ao Brasil para a realização das mesmas e envidou esforços protelatórios durante a apuração. A partir desse cenário, o relatório publicou a declaração na qual afirmava ter encontrado fortes indícios de graves violações de direitos humanos no país, recomendando a investigação e punição dos responsáveis. Devido à censura à imprensa e às medidas protelatórias visando retardar sua publicação, esta decisão histórica não foi amplamente divulgada no país (Green, 2009).

A CIDH fracassou ao não transformar o Brasil em alvo efetivo de críticas e pressões, mas estabeleceu jurisprudência para outros países atingidos por ditaduras, tais como o Chile e a Argentina (Id., p.305-6). Nesse período, a Comissão Interamericana possuía um perfil baixo e pouco efetivo de atuação. Suas atividades eram muitas vezes ditadas pela lógica da Guerra Fria e da agenda dos Estados Unidos. A CIDH padecia de uma carência crônica de recursos e de isolamento institucional no âmbito da OEA. Sua composição era conservadora e sofria ingerências externas dos Estados, podendo ser considerada como pouco consolidada (Bernardi, 2018, p. 1131-34).

Na Europa, por outro lado, desde 1969 a Anistia Internacional (Al) investigava as violações de direitos humanos no Brasil. Depois de tentar várias vezes obter autorização do governo brasileiro para conferir in loco as denúncias recebidas, publicou em Londres o Report on Allegations of Torture in Brazil, em setembro de 1972. Em resposta, o governo brasileiro proibiu qualquer divulgação a seu respeito no país (Biocca, 1974, p. 9; Martins Filho, 2019, p. 71-95). Nesse período, porém, a opinião pública internacional já não duvidava de que a tortura era uma política de Estado no Brasil.

Com efeito, entre março e abril de 1974, as denúncias de abusos ocorridos no Brasil ganharam grande repercussão no Tribunal Bertrand Russell II. Embora sem a magnitude do Tribunal que apurou os crimes cometidos na Guerra do Vietnã em 1968, sua segunda versão expôs os abusos cometidos no Brasil. Sediado em Roma, o julgamento foi iniciado com a leitura do relatório do juiz italiano Salvatore Senese, no qual apresentou um panorama da situação do direito no Brasil. Miguel Arraes apresentou a acusação contra o país e ex-presos políticos e familiares de dissidentes assassinados apresentaram seus testemunhos. A sentença do tribunal

${ }^{29}$ Cf. Santos (2009), p. 479 e Bernardi (2018). A CNV recebeu a documentação dos arquivos da CIDH, mas não procedeu à análise da mesma, cf. CNV (2014), p. 205-13. Agradeço as indicações de leitura e observações de Bruno Boti Bernardi a respeito da $\mathrm{CIDH}$. 
concluiu que a amplitude das violações aos direitos humanos verificadas no Brasil configurava a prática de crimes contra a humanidade (Tosi; Guerra, 2014, p. 323-34).

No âmbito da Organização das Nações Unidas (ONU), o Estado brasileiro lidou com inúmeras denúncias, enviadas por distintas instituições, como a Federación de Obreros y Campesinos Cristianos, da Costa Rica, e a Unión Nacional de Mujeres Mexicanas. Em 1971, a Alianza de Mujeres Costarricenses solicitou à Comissão de Direitos Humanos (CDH) que investigasse a situação de cerca de duas mil mulheres submetidas a torturas nas prisões brasileiras. Em setembro do ano seguinte, a Women's International Democratic Federation encaminhou comunicação sobre a perseguição e o assassinato de cerca de 350 mulheres brasileiras. A Anistia Internacional e a Liga Internacional para Direitos do Homem solicitaram ao Subcomitê de Prevenção à Discriminação e Proteção de Minorias da ONU que analisasse o "consistente padrão de graves violações de direitos humanos" verificado no Brasil, conforme as denúncias compiladas no relatório da Anistia Internacional mencionado anteriormente (CNV, 2014, vol. I, p. 201).

O governo estava preocupado com as "campanhas no exterior", embora o volume de alegações relativas ao Brasil decrescesse, uma vez que o auge das denúncias enviadas aos organismos multilaterais ocorreu entre 1969 e 1972. A ditadura temia que uma possível "condenação" tivesse o efeito de "estimular as forças de oposição ao governo [...] a prosseguir e ampliar seus esforços difamatórios", e avaliava que o interesse pelo tema seria duradouro. A partir de 1974, o Brasil se tornou objeto de consideração, no procedimento confidencial da ONU. As comunicações diziam respeito ao genocídio dos povos originários, à tortura e assassinatos de adversários políticos do regime, à injustiça social e aos objetivos expansionistas do Brasil na região (CNV, 2014, vol. I, p. 202).

Com efeito, em 1974, foi formado um grupo de trabalho interministerial (GTI), integrado por representantes do Ministério das Relações Exteriores (MRE), do MJ, da Secretaria do Conselho de Segurança Nacional (CSN) e do SNI, "para examinar questão relevante ou para proceder a avaliações periódicas do quadro internacional". A linha de ação a ser seguida descartava o diálogo com os grupos internacionais de pressão e determinava o acompanhamento especial à tramitação de denúncias encaminhadas aos sistemas ONU e OEA. ${ }^{30}$

A estratégia do governo era aprofundar a participação do Brasil em ambos os sistemas, buscando a reeleição na CIDH e o ingresso na CDH da ONU em 1975. Dois anos depois, o Brasil conseguiu se eleger em um dos lugares correspondentes à América Latina. Seu objetivo era garantir que as denúncias fossem "rejeitadas, desacreditadas" ou seu exame adiado, levantandose "todas as suspeições cabíveis sobre sua credibilidade", desde que mantidas as aparências. 0 MJ assumiria a função de órgão de coordenação interna dessa orientação, adotada no âmbito da OEA havia alguns anos, em conformidade com as diretrizes do MRE (CNV, 2014, vol. I, p. 208-13).

Embora a primeira denúncia tenha chegado à ONU em setembro de 1972, somente em maio de 1975 o governo brasileiro analisou formalmente as alegações apresentadas pela

30 Cf. CNV (2014), cap. 5; ARQUIVO NACIONAL, DSI/MJ: BR_RJANRIO_TT_O_MCP_PRO_432, Processo DICOM no 59.947 , de 11 de julho de 1975. 
entidade. O governo negou a procedência das denúncias e afirmou que a CDH deveria evitar tomar decisão "precipitada e insuficientemente informada", uma vez que os casos estavam sob análise das autoridades brasileiras (CNV, 2014, vol. I, p. 204).

O Grupo de Trabalho sobre Situações da ONU realizou cinco encontros para discutir denúncias referentes ao Brasil. O grupo declarou-se impossibilitado de verificar a existência dos recursos jurídicos e o respeito a eles, com base na resposta oficial do governo brasileiro. Registrava que não foram recebidas novas comunicações desde a 31a. sessão da CDH (1975), concluindo que não era necessária nova ação. Encerrava-se, assim, o exame confidencial da situação do Brasil (Alves, 1994, p. 88-89), reproduzindo o fracasso da OEA, no que diz respeito à efetividade de suas pressões.

As denúncias das graves violações aos direitos humanos cometidas no Brasil não alcançaram a mesma repercussão que as de outros países da região, posteriormente. Não obstante, geraram desgaste à ditadura militar. Sua difusão exerceu influência sobre a conjuntura política, coincidindo com o surgimento dos primeiros sinais de esgotamento do "milagre econômico". A seguir, analisaremos a conjuntura econômica na qual se consolidou a proposta de institucionalização da ditadura, visando remodelá-lo sem estabelecer, contudo, mudanças substanciais na ordem política e social.

\section{Os abalos iniciais do "milagre econômico"}

No início dos anos 1970, a percepção dos primeiros sinais de erosão de legitimidade do governo constituiu um elemento significativo do contexto político, motivando os militares a elaborar um projeto de distensão política gradual. A iniciativa refletia certa consciência de que os indícios de desgaste político estavam associados tanto à difusão das denúncias de graves violações dos direitos humanos quanto ao próprio desempenho econômico do país.

Essa abordagem da conjuntura econômica, contudo, não é consensual, segundo a análise de alguns autores, que assinalam que os efeitos da crise do chamado "milagre econômico" não eram plenamente visíveis no período inicial dos debates acerca da proposta de distensão política (Lemos, 2014, p. 560). Por outro lado, autores como Paul Singer apontam uma série de evidências, que revela um cenário econômico problemático e perceptível para diversos analistas. Segundo esta perspectiva, apresentamos o panorama da economia brasileira desse período.

Desde 1968, a economia brasileira estava em expansão, devido ao "milagre econômico". A política econômica do governo visava estabelecer a "legitimação pela eficácia" (Prado e Earp, 2003, p. 220), cuja expansão iria beneficiar-se do crescimento expressivo da economia mundial (Singer, 1977, p. 15). Em 1971, porém, esta começava a apresentar sinais de esgotamento, conforme Paul Singer. Em agosto daquele ano, Nixon anunciou que os EUA abandonariam o sistema de taxas de câmbio fixas, cuja âncora monetária internacional era a paridade dólarouro, desde os acordos de Bretton Woods de 1944. Esta decisão unilateral é decorrente do ônus causado pela Guerra do Vietnã, custeada com dinheiro emprestado e o consequente 
déficit orçamentário provocado nas contas do país. A medida propiciou a desvalorização do dólar e das moedas europeias, encarecendo as importações de diversos países. ${ }^{31}$

Em âmbito nacional, entre 1968 e 1973, o Brasil alcançaria altas taxas de crescimento (de 10 a 13,97\% a.a.), mantendo a inflação em níveis "aceitáveis" (menos de 25\%), por meio do controle administrativo dos preços e da sistemática redução dos salários dos trabalhadores. A economia não mais apresentava capacidade produtiva ociosa, aumentando a acumulação de capital, na medida em que os crescentes salários da tecno-burocracia e da nova classe média estimulavam o consumo. O modelo econômico de desenvolvimento adotado promovia a contenção dos salários da mão de obra não especializada, resultando em expressiva concentração salarial e em um crescimento explosivo da demanda por bens e serviços de alto padrão (Singer, 1977, p. 108). Este cenário, porém, apresentava indícios de fragilidade (Bresser Pereira, 1980).

Desde os anos 1960, o papel de "entreposto industrial" assumido por países de grande extensão territorial, ampla população e regime político "seguro" (o que significa, na maioria das vezes, ditatorial), ligou-os às economias centrais do mundo, com a função de desenvolver linhas de produção que requeriam mão de obra e recursos naturais abundantes. Essa estratégia de desenvolvimento adotada pelo Brasil se beneficiou do processo de globalização, em um contexto de crescente domínio das empresas multinacionais, possibilitando ao governo atrair grandes volumes de capital estrangeiro (sobretudo dólares), por meio de uma generosa política de isenções e subvenções fiscais, assim como a transferência de tecnologia e a penetração em mercados fechados a empresas brasileiras (Singer, 2014, p. 191).

Após o impacto das reformas conservadoras de Castelo Branco, o governo passou a estimular a agricultura e a exportação, visando obter maior equilíbrio da balança comercial e de pagamentos. Observa-se então um surto de exportações no país, registrando-se um aumento significativo da venda de produtos industriais. Essa estratégia, contudo, apresentava contradições: a política de substituição de importações produziu uma estrutura industrial que demandava mais importações em curto prazo, porque abrangia áreas em que a tecnologia era sofisticada e sujeita à rápida obsolescência. Por outro lado, o capital proveniente da exportação ajudava a financiar o déficit comercial causado pelo aumento das importações, indispensáveis para manter o desenvolvimento acelerado.

A integração do Brasil ao mercado mundial apresentava dois aspectos irreconciliáveis com o desenvolvimento autônomo: o país passou a depender de parcelas importantes do mercado de países desenvolvidos e do crescente fornecimento externo de tecnologia, equipamentos e algumas matérias-primas. Ao se especializar em produtos industriais necessários aos países centrais com baixo valor agregado, tais como calçados, café solúvel, suco de laranja e componentes de sistemas de processamentos de dados, o Brasil deixou de substituir importações essenciais, sobretudo de know-how tecnológico e de bens de capital (entre elas as de máquinas de fabricar calçados e computadores), passando a depender do fornecimento externo.

${ }^{31}$ Cf. Judt (2008), p. 457-58. Os EUA esboçaram uma recuperação com taxas de crescimento de 5,7\%, em 1972, e de 5,5\%, em 1973. O Japão, França e a Alemanha mantiveram elevado crescimento nesse período, cf. Macarini (2005, p. 78). 
Os governos militares limitaram-se à substituição de importações de algumas indústrias de bens intermediários, como a da indústria petroquímica, sem estendê-la a setores essenciais como o de equipamentos, que incorporam tecnologia de vanguarda. A abertura ao mercado mundial resultou no aprofundamento da dependência financeira e tecnológica entre os países periféricos e os de economias centrais. No Brasil, apenas os ramos de atividades nos quais as empresas estatais atuavam - sobretudo os de petróleo, transportes e mineração - ficaram relativamente protegidos da expansão das multinacionais.

Nesse período, o governo reformulou a organização do sistema financeiro, incentivando a centralização dos capitais bancários, o que conduziu a uma rápida concentração bancária e à formação de grandes conglomerados financeiros. Estas mudanças permitiram a ampliação de crédito, sobretudo para o setor agrícola (Singer, 1977, p. 91-116, 224-25), criando-se um sistema, a partir da progressiva ascensão dos bancos de investimento, com o objetivo de viabilizar a expansão das grandes empresas. O Estado passou a investir em grandes obras, estimulando a construção civil, por meio da criação do Banco Nacional de Habitação (BNH) em 1964, encarregado de ampliar o crédito ao setor, o que produziu um amplo efeito multiplicador (Singer, 2014, p. 193).

Em janeiro de 1970, motivado pela vigorosa recuperação econômica em curso, o ministro de Fazenda do general Médici, Delfim Netto, adotou uma nova estratégia de desenvolvimento, o modelo "agrícola-exportador", que mudava a cautelosa e sóbria postura anterior, apostando "alto", em consonância com as aspirações políticas do projeto "Brasil Grande Potência". Este projeto, esboçado a partir de 1967, consistiu no núcleo da política de desenvolvimento e do modelo de crescimento adotados. Apostava-se no incremento da produção agrícola e das exportações, para possibilitar uma rápida ampliação do mercado interno e induzir o crescimento de outros setores da economia. Delfim pretendia promover o crescimento da diversificada indústria já existente no país, paralelamente ao controle inflacionário (Macarini, 2005, p. 59-67).

Vale lembrar que a economia brasileira apresentava um panorama complexo, no qual alguns setores da sociedade prosperavam significativamente. A despeito da superexploração da força de trabalho, parte da população mais pobre experimentava alguma melhoria de vida. Entre 1970 e 1976, a redução da pobreza absoluta ocorreu nos setores urbano e rural. A pirâmide social brasileira continuava a apresentar uma base maciça de pobres, mas esta se reduziu um pouco, enquanto a cúpula se ampliava consideravelmente (Singer, 1986, p. 3942). Este cenário contribuiu para garantir longevidade à ditadura, favorecendo a eclosão do processo de distensão política, assim como certo controle sobre a transição à democracia.

A expansão da demanda e dos custos da produção, porém, acarretou um novo ciclo de alta da inflação. No início do ano de 1970, "o ano da agricultura", no qual o governo criou incentivos para o setor, visando a ampliação da mecanização e do uso de insumos modernos, já eram perceptíveis os sinais de incômodo, quanto ao aumento de preços. Este cenário suscitava inquietação em determinados setores. Neste contexto, a política econômica voltou-se com ênfase para o controle inflacionário, ao estabelecer a redução das taxas de juros, assumindo a meta de 15\% para 1972 e de 12\% para 1973 (Macarini, 2005, p. 67-68, 73-83). A sucessão 
de Médici despontava e a "nova postura", além de revelar preocupação com o desgaste do regime, visava aumentar o cacife do grupo dirigente, a fim de influir neste processo.

Esses esforços, porém, não evitaram as dificuldades: o sistema de transporte passou a não dar vazão às mercadorias, diversas matérias-primas e insumos faltaram no mercado interno e externo, e outros serviços, como os de telefonia, vergaram diante da demanda excessiva (Singer, 1977, p. 117). A concentração de renda, por sua vez, apresentava seus efeitos. Em maio de 1972, o líder do MDB, Alencar Furtado, fez duras críticas aos efeitos nefastos do agravamento das desigualdades sociais no Brasil. Por outro lado, no mês de dezembro, o presidente do Supremo Tribunal Federal (STF), Aliomar Baleeiro, declarou que era impossível obter desenvolvimento econômico continuado sem democracia (Skidmore, 1988, p. 284-85).

O boom sincronizado do capitalismo "avançado" havia intensificado a demanda mundial por alimentos e matérias-primas industriais. Ao longo de 1972 e 1973, a demanda de crédito impulsionada pelos incentivos promovidos pelo "milagre" foi atendida com mais oferta de crédito. As exportações brasileiras receberam subsídios do governo, favorecidas pela isenção fiscal, mas a necessidade de importações de curto prazo, combinada aos déficits do setor de serviços ultrapassou as cifras obtidas.

Dissemina-se, então, a percepção de escassez no Brasil e tem início a antecipação de compras, contribuindo para intensificar a carência de matérias-primas e insumos, e a correspondente pressão sobre os preços. Ao longo de 1973, as pressões pelo crescimento da demanda e o impacto da inflação externa se fizeram sentir no aumento das taxas inflacionárias. ${ }^{32}$ A taxa de crescimento do setor agrícola estagnou em 3,5\%, enquanto o problema da dívida externa (no patamar de 12 bilhões de dólares) indicava o estrangulamento do projeto de desenvolvimento do governo. As contradições do modelo econômico adotado ficavam mais visíveis (Singer, 1977).

Nesse contexto, o governo manipulou os índices inflacionários de 1973, maquiados a partir do uso de preços tabelados. A inflação oficial foi calculada em 16\%, enquanto a taxa medida pelo Departamento Intersindical de Estudos e Estatísticas de Salários (DIEESE) era de 26\%. Desde 1971, despontavam discrepâncias nos números referentes à inflação, conforme revelaram os dados do DIEESE publicados em $1977 .{ }^{33}$

O debate sobre os custos sociais do modelo econômico brasileiro passou a ocupar mais espaço na mídia e os setores médios começaram a inquietar-se com os indícios de problemas econômicos mais sérios. A esses fatores somou-se outro aspecto da conjuntura internacional - a crise do petróleo. A guerra do Yom Kipur, desencadeada em setembro de 1973, acarretou aumento dos preços do petróleo, reforçando o desequilíbrio no balanço de pagamentos do Brasil, que não possuía autonomia em sua produção nem de seus derivados.

O índice de crescimento econômico de 1973, porém, permaneceu alto, alcançando quase $14 \%$, mas a explosão dos preços do petróleo e suas repercussões fizeram com que a inflação subisse ainda mais. Em 1974, a taxa da inflação oficial foi de 34,5\%, chegando a $120 \%$

\footnotetext{
32 O governo adotou restrições às exportações, impôs tabelamento de preços, ampliou o crédito durante a entressafra e 0 incentivo à importação para a criação de estoques, cf. Macarini (2005, p. 87-89).

33 A manipulação das taxas da inflação de 1973 veio a público em 1977, desencadeando a instalação de uma CPI na Câmara Federal e a organização das greves de 1978 (Bresser Pereira, 1980, p. 108; Macarini, 2005, p. 88-9).
} 
até o final da década. A inflação mundial se transformou em mais uma cortina de fumaça a encobrir os problemas estruturais da economia brasileira. As altas taxas de crescimento brasileiro desaguaram numa conjuntura de superaquecimento, com os níveis de produção alcançando o teto da plena utilização de sua capacidade (Singer, 1977, p. 157; Skidmore, 1988, p. 281).

Com os primeiros sinais de declínio do "milagre econômico", o apoio de setores das camadas médias ao governo ficou abalado, ${ }^{34}$ enfraquecendo a base de sustentação da ditadura. Em meados de 1973, a perspectiva de que havia chegado o momento de promover alguma mudança era comum. Lideranças militares admitiam o desgaste e empenhavam esforços para conceber uma proposta de "distensão política" (Alves, 1984, p. 177-78, 186; Mathias, 1995, p. 63), que garantisse certa legitimidade e aparência de legalidade ao regime. Reformas seriam promovidas, para alterar as aparências sem mexer no essencial, daí a centralidade da estratégia de desaparecimento forçado dos dissidentes políticos.

A derrota do partido do governo - a Arena - nas eleições de 1974 constituiu outro importante elemento a exercer influência sobre o avanço das denúncias de abusos aos direitos humanos, assim como sobre o ritmo das negociações a respeito do projeto de descompressão política. Desde esta perspectiva analisamos, na próxima seção, os aspectos decisivos concernentes à estratégia repressiva adotada nesse período e sua interface com a distensão política, os quais ainda são pouco estudados.

\section{O projeto de distensão política}

Para melhor compreender o contexto histórico no qual teve início a articulação do projeto de descompressão política gradual no Brasil, cabe lembrar que, entre os anos de 1971 e 1972, no auge da repressão promovida pelo governo Médici (1969-1974), intensas movimentações em torno da sucessão presidencial ocorriam nos bastidores da política. Articuladas pelo general Golbery do Couto e Silva, essas negociações tinham por objetivo conduzir o projeto de institucionalização da ditadura, tendo em vista o quadro de erosão de sua legitimidade que se delineava aos olhos de diversos analistas. $O$ projeto pretendia evitar as crises que cercaram as duas "sucessões presidenciais" anteriores e criar as condições necessárias a uma estabilidade mais duradoura do regime. Em curso desde junho de 1971, a "candidatura" do general Ernesto Geisel ancorava-se nessa proposta, que encontrava eco entre líderes civis, para além das fronteiras da Arena (Mathias, 1995, p. 54; Skidmore, 1988, p. 322).

Nesse período, o general Médici apontava na direção da institucionalização do regime. No início de 1972, o governo adotou medidas voltadas à aproximação do partido da situação ao centro decisório, com vistas a dirigir mais de perto o Congresso Nacional. Médici manteve forte controle sobre a Arena, inclusive após sua vitória nas eleições de 1970, escolhendo antigos membros da UDN e do PSD para postos de liderança, a fim de ampliar sua influência sobre o

\footnotetext{
${ }^{34}$ Surgem outros sinais de fissuras em sua base de apoio, como a saída do ministro da Agricultura, Cirne Lima, do governo, cf. Macarini (2005, p. 90).
} 
partido (Mathias,1995, p. 54; Skidmore, 1988, p. 295).

Em meados de 1972, o ministro-chefe do Gabinete Civil da Presidência da República, Leitão de Abreu, tomou a iniciativa de discutir a questão, com figuras como o professor Cândido Mendes, influente líder católico e cientista político. ${ }^{35}$ Por meio de sua mediação, o governo convidou o cientista político norte-americano e professor de Harvard, Samuel Huntington, ${ }^{36}$ para realizar uma série de conversas palacianas no Brasil, em outubro de 1972. Huntington defendia uma distensão lenta e controlada de regimes autoritários, constituindo-se em um interlocutor de peso na formulação de um projeto desse tipo. ${ }^{37} \mathrm{O}$ professor de Harvard participou de longas conversas sobre a liberalização do sistema político, com Leitão de Abreu e Delfim Netto, que reconheceram a necessidade de "[...] extinção das formas extremas de repressão [...]" (Skidmore, 1988, p. 323).

Em 1973, em resposta à solicitação de Leitão de Abreu, Huntington preparou um documento sobre a liberalização política no Brasil, no qual afirmava que:

A descompressão eficaz e duradoura deve ser, portanto, um processo gradual sobre o qual o governo mantenha firme controle. Para conseguilo são desejáveis [...] Primeiro, a iniciativa [...] deveria partir do governo. [...] Não deveria parecer render-se a pressões ou exigências de grupos oposicionistas, porque [...], tais exigências entrarão em uma escalada e o governo poderia facilmente perder o controle do processo. Além disso, a descompressão deveria conduzir a novas formas políticas, [...] e não a uma restauração artificial de práticas pré-64. ${ }^{38}$

De acordo com o professor, tal programa deveria ser apoiado por "um consenso entre os grupos dominantes do governo" e requeria atenção à condução das diversas fases do processo: primeiro, uma condução "à institucionalização, depois à expansão da participação e da representação e, finalmente, à liberalização". Atenção especial deveria ser dispensada à "cooptação de grupos potencialmente oposicionistas", o que seria menos custoso do que tentar "reprimir tais grupos" (Huntington, 1973, p.4). Por fim, concluía que, se o governo não estabelecesse tal processo, "os grupos e movimentos oposicionistas certamente lhe" tirariam a iniciativa. O rápido desenvolvimento econômico do Brasil geraria mudanças na estrutura político-social do país, acarretando conflitos e instabilidades políticas (Huntington, 1973, p.1011).

\footnotetext{
35 Mendes era dirigente da Comissão Brasileira de Justiça e Paz e ajudou a disseminar as teses sobre a "descompressão política" de Huntington durante o governo Médici. Foi um dos articuladores da criação da Comissão Tripartite, composta por líderes católicos, empresários e militares, visando ao exame secreto de denúncias de violações de direitos humanos, cf. Serbin (2001). A atuação da CBJP foi bem mais tímida do que a da CJP/SP, comandada por D. Paulo E. Arns, cf. Benevides (2008).

${ }^{36}$ Sua primeira visita ao país, articulada por Mendes, ocorreu em outubro de 1965 (Lemos, 2014, p. 561). Huntington estava ligado ao Estado norteamericano por vários laços e instituições. Nesse período, era uma espécie de "emissário informal" do secretário de Estado Henry Kissinger (Gaspari, 2002, p. 330-332) e um "intelectual orgânico" do capital transnacional (Hoelever, 2012, p. 34-36).

37 Em 1968, Huntington defendeu que caberia aos militares, sobretudo os brasileiros, moldar a nova ordem política, para obter maior estabilidade institucional. Caso contrário, a inicitiva política passaria "para outros líderes de classe média, os quais são os apóstolos da revolução", cf. Huntington (1968, p.262). Nesse período, sociólogos norteamericanos defenderam que somente os militares poderiam assumir a tarefa de "construir a nação" nos países em desenvolvimento, cf. Comblin (1978, p. 143-44).

38 Cf. Huntington, Samuel. Métodos de descompressão política, 1973, p. 2. Disponivel em: <https://www.docvirt.com/docreader. net/docreader.aspx?bib=ACER_PNB_PIgpasta=PNB\%20pi\%20Huntington,\%20S.1973.00.008pagfis=1557>. Acesso em: 20 fev. 2020
} 
O diálogo estabelecido entre assessores de Médici e Huntington sugere proximidade com a perspectiva do general Ernesto Geisel e seu grupo. Não por acaso, Geisel foi indicado sucessor de Médici. Sua "candidatura", lançada em 15 de setembro de 1973, ocorreu logo após o golpe de Estado desfechado contra Allende no Chile, que contou com o apoio decisivo dos EUA e do Brasil. Huntington voltou ao Brasil em fevereiro de 1974, a convite de Golbery, para debater a proposta de institucionalização e descompressão do regime. ${ }^{39}$

Nesse período, a administração Nixon/Kissinger adotou uma postura ambígua nas relações internacionais. Enquanto apoiava ou promovia golpes militares na América Latina, tais como os do Chile e do Uruguai em 1973, iniciava uma Détente (Distensão) no âmbito internacional. O país se aproximou da China, estabeleceu o acordo SALT 1 com a União Soviética, em 1972, e formalizou o acordo de paz com o Vietnã em 1973 (cujo cessar-fogo foi quebrado pelos EUA), entre outras medidas (Judt, 2017, p. 348).

É nesse contexto que a proposta de institucionalização e flexibilização da ditadura ganha adeptos no Brasil, tais como Wanderley Guilherme dos Santos, então diretor do Departamento de Ciência Política da Faculdade Cândido Mendes. Em setembro de 1973, ele proferiu uma conferência no Instituto de Pesquisas, Estudos e Assessoria do Congresso Nacional (IPEAC), presidido pelo senador José Sarney (Arena/MA), na qual apresentou uma sofisticada proposta de distensão política gradual e "controlada pelo alto". A imprensa deu publicidade à conferência, destacando as semelhanças de sua análise com as de Huntington (Skidmore, 1988, p. 324-27; Hoelever, 2012, p. 44-5).

$\mathrm{Na}$ conferência, Santos afirmou que o país começava a apresentar sinais de "crise institucional", agravada pelas divisões internas entre os militares, cuja superação exigiria um acordo que conferisse previsibilidade à descompressão política. Para ele, a distensão política, orientada por uma estratégia "incrementalista", era a alternativa mais adequada para as mudanças demandadas. Sua principal preocupação também dizia respeito ao ritmo da descompressão, a qual deveria ser implementada de forma a minimizar os riscos de retrocesso autoritário (Santos, 1978, p. 153-54).

Para Santos, o procedimento gradualista facilitaria a aquisição de apoios e consensos, possibilitando a formação de coalizões em torno de propostas específicas, sublinhando a necessidade de o governo não abrir mão de sua capacidade de coagir, substituindo-a por mecanismos específicos que obrigassem os setores liberados "a não extravasarem os limites da descompressão." O regime deveria criar mecanismos de coação "suficientemente fortes e de rápida aplicação" e, paralelamente, disseminar "lealdade", resultante de sua capacidade de persuasão, respeitando a agenda de prioridades estabelecida (Santos, 1978, p. 155-58).

A conferência provocou intenso debate, no qual o deputado "autêntico" do MDB, Lysâneas Maciel, declarou-se desapontado, pois a proposta coincidia com a política defendida por diversos líderes arenistas. Segundo ele, caso este modelo fosse adotado, seriam necessárias "décadas" para tornar possível a "redemocratização brasileira" (Santos, 1978, p. 181-82). O senador pernambucano Marcos Nobre (MDB), por seu turno, atacou a estratégia, pois esta

39 Huntington voltou ao Brasil em agosto de 1974 para debater o tema em um seminário no Rio de Janeiro, cf. Skidmore (1988), p. 321, 326-27. 
favorecia "regiamente aqueles que justificam o autoritarismo", defendendo um modelo de transição resultante da deposição dos militares e a imediata convocação de uma Assembleia Constituinte, conforme sua interpretação da transição de 1945 (Skidmore, 1988, p. 325).

Note-se que esse projeto de distensão estava articulado ao "temor onipresente" de regressão autoritária, atuando como uma "espada de Dâmocles", uma ameaça latente sobre a "sociedade civil", com o objetivo de paralisar os atores políticos pelo medo. Esta ameaça tornou-se um importante instrumento para moderar a velocidade do processo, contaminando a estratégia das oposições (Quinalha, 2013, p. 89-93).

No governo havia acordo em torno da necessidade de superar a crise de legitimidade, ainda que não houvesse concordância sobre a maneira de condução. Militares e civis defendiam a permanência do Al-5 até que se encontrasse uma fórmula consensual. $\mathrm{O}$ projeto de liberalização partia da premissa de que não seria possível manter um regime de exceção, considerado transitório, sem promover sua institucionalização, pela adoção de regras duradouras (Mathias, 1995, p. 57-63).

A indicação de Geisel para a sucessão presidencial circulava na imprensa desde 1971, mas, segundo o general Golbery, seu projeto de institucionalização havia sido estruturado em 1969 (Gaspari; Hollanda; Ventura, 2000, p. 319), vinculado à "candidatura" de Geisel. Semelhante às propostas mencionadas antes, ele pretendia aproximar o governo da elite da "oposição responsável" (Skidmore, 1988, p. 323-25), ao mesmo tempo em que afirmava ter por objetivo o combate aos polos à esquerda e à direita. De acordo com a estratégia das "sístoles e diástoles", sua metáfora biológica,

os alvos preferenciais deverão ser as extremas da direita ou esquerda, permitindo-se aos elementos mais moderados delas desvincularem-se. [...] Não perder oportunidades de ação sempre que a esquerda ou a direita se excedam, tanto mais quanto mais flagrantes sejam os seus excessos: graduar as reações de modo a nunca enfraquecer demasiadamente - quanto mais eliminar prematuramente - qualquer das extremas em reforço à outra, o que possivelmente viria a ser comprometedor para a posição central e isenta do Governo (Couto e Silva, 2003, p. 475-500. Destaques nossos).

O governo precisava criar mecanismos que permitissem a sustentação do regime no poder, mantendo a coesão entre as alas militares em conflito, agregando setores moderados da oposição e da imprensa. Golbery pretendia manter o controle do poder e demonstrar (ou melhor, fazer transparecer) a independência política do governo, estabelecendo uma representação de "estadista moderado" para Geisel. A orientação era a de não "eliminar prematuramente" quaisquer dos extremos do espectro político-ideológico, expressa na seletividade da repressão política, a qual diferia conforme o alvo e o período (Teles, 2005, p. 76-79). Note-se que, em 1974, Golbery acenou com a retirada paulatina da censura das redações da grande imprensa e a aposta na continuidade da autocensura. Desse modo, o panorama se alterava sem deixar de lado a repressão, que não deveria ser noticiada. Mudariam algumas atitudes do governo Geisel, 
mas também deveriam ser alteradas as diretrizes dos jornais. ${ }^{40}$

Em consonância com essa estratégia, em meados de 1973, Geisel propõe a mudança do slogan governamental de "desenvolvimento com segurança" para "continuidade sem imobilidade". Por "continuidade" entendia-se obediência às linhas mestras do modelo econômico de desenvolvimento estabelecido, assim como aos parâmetros do modelo repressivo (Teles, 2005, p. 76-78). "Sem imobilidade" era traduzida nas reformas, com vistas à liberalização progressiva do regime e o aprofundamento de seu projeto desenvolvimentista (Alves, 1984, p. 186).

Essa perspectiva ganhou respaldo, embora estivessem em disputa diversos caminhos possíveis de preservação das prerrogativas do Executivo (Mathias, 1995, p. 64-5). Com efeito, a estratégia de descompressão política gradual mostrou-se uma engenhosa maneira de manter os militares no poder por longo período. As distintas propostas de distensão previam algum grau de institucionalização do regime (relativo à incorporação do Al-5 à Constituição), o que pressupunha o controle das oposições, assim como dos diferentes grupos militares em conflito.

A seguir, analisamos a adoção do desaparecimento forçado, entre outras estratégias repressivas, nesse período, assim como o respeito à hierarquia militar.

\section{Eliminar, "sem deixar vestígios"}

Para compreender o período inicial da distensão política, faz-se necessário retornar ao ano de 1971, quando se consolida o processo de centralização e militarização do aparato repressivo no Brasil. Desenvolvia-se, então, intensa perseguição contra os dissidentes da ditadura e forte controle sobre a sociedade. A estrutura repressiva utilizada possuía diversas nuances conjunturais, enquanto mantinha suas características essenciais, a saber, seu caráter centralizado e seletivo, permeado por preocupações com a legitimidade institucional do Estado de Segurança Nacional. A eficiência do sistema repressivo brasileiro possibilitou sua exportação para outros países, sobretudo para o Chile e o Uruguai, a partir de 1973, conforme revela um documento militar. ${ }^{41}$

Assiste-se a uma crescente política de eliminação de perseguidos políticos no Brasil. Em 1971, com a criação de centros clandestinos de detenção, sobretudo da "Casa da Morte" de Petrópolis (RJ), a orientação predominante gradativamente torna-se desaparecer com os militantes que faziam oposição ao regime, eliminando-os, "sem deixar vestígios". A fase final da repressão à Guerrilha do Araguaia (1972-1974), desencadeada em outubro de 1973, marca o período de consolidação dessa estratégia. A distância dos principais centros urbanos e o declínio da legitimidade do regime favoreceram a decisão. Não interessava ao governo divulgar a existência de conflitos armados patrocinados por comunistas no Brasil.

\footnotetext{
40 Entre 1974 e 1975, Golbery costurou o apoio de proprietários de meios de comunicação e jornalistas escolhidos para "colaborar" e "viabilizar" o projeto de distensão. A retirada negociada da censura ocorreu em alguns periódicos da "grande imprensa" (Duarte, 1987)

${ }^{41}$ De acordo com esse documento, oficiais de Informação dos Exércitos argentino, chileno e uruguaio avaliaram de maneira positiva o sistema de informação do Brasil. Em decorrência, o Chile e o Uruguai adotaram sistemas semelhantes, com sucesso superior ao da Argentina, cf. SISTEMA de Segurança Interna no País (SISSEGIN). [S. l.: s. n., 1974], p. 44-45.
} 
A partir de 1973 houve uma redução dos assassinatos mascarados por falsas versões de suicídio, atropelamentos ou confrontos em tiroteios fictícios. Emerge a figura do desaparecido político: aquele sobre o qual não mais havia a notícia da morte, um corpo ou atestado de óbito. Com o desaparecimento de uma pessoa e a inexistência de um momento de luto, apagavase a distinção entre passado e presente. A onipresença da morte, que ofusca essa diferença, dificulta o surgimento de representações de um corte, de um antes e um depois (SeligmannSilva, 2000, p. 85-93), e de uma memória social. O medo e a incerteza se disseminam.

O desaparecimento forçado se transforma em estratégia repressiva, inicialmente, para encobrir as operações de infiltração, sobretudo de militantes transformados em agentes policiais. O desaparecimento é adotado por ser considerado uma estratégia com maior eficiência operacional. Em depoimento à CNV, o coronel reformado Paulo Malhães assumiu sua participação como um dos mentores do centro clandestino de extermínio de Petrópolis, considerado como um "laboratório" da repressão. Ele admitiu seu envolvimento em torturas, mortes e ocultação de cadáveres. De acordo com suas palavras, o surgimento dessa estratégia ocorreu

Quando o troço virou guerra [...], é que as coisas mudaram. Porque a gente também foi aprender fora, alguma coisa. Aí os perfis das prisões daqui mudaram; a forma de contato com os presos mudou; surgiu a necessidade de aparelhos; porque [...] o que causa maior pavor não é você matar a pessoa. É você fazer ela [sic] desaparecer. O destino fica incerto. [...] o que irá acontecer comigo? Eu vou morrer? Não vou morrer? [...] O pavor é muito maior com o desaparecimento do que com a morte. A morte, não, você vê o cadáver do cara, o cara ali, acabou. Não tem mais... o que pensar nele [sic]. [...] Já quando você desaparece - isso é ensinamento estrangeiro - [...] você causa um impacto muito mais violento no grupo. Cadê o fulano? Não sei, ninguém viu, ninguém sabe. Como o cara sumiu? ${ }^{42}$

Além dos centros clandestinos criados com esse objetivo, os IML, serviços funerários, cemitérios públicos e a Justiça Militar - em especial de São Paulo, Rio de Janeiro e Pernambuco - envolveram-se em operações executadas com a finalidade de encobrir o assassinato e o desaparecimento de perseguidos políticos. Essas operações conduziram à constituição de valas clandestinas em cemitérios, tais como a vala de Perus, em São Paulo (Teles, 2005; Almeida et al., 2009).

Em seu depoimento, Paulo Malhães sublinhou que o sepultamento de vítimas não era estratégico para a repressão, na medida em que "deixava rastros". Por fim, revelou que os corpos de militantes desaparecidos pelo Exército eram lançados em rios, após sua descaracterização, pois o mar os "devolvia". Para tanto, eram cortadas as falanges dos dedos e a arcada dentária da vítima era arrancada, além de cortar o ventre para evitar a produção de gases durante a decomposição. Em seguida, o corpo era colocado em um saco impermeável com pedras,

\footnotetext{
42 Cf. CNV (2014), p. 500. Malhães foi assassinado em 25/04/2014, cf. "Morto na quinta-feira, coronel Paulo Malhães temia por sua vida". São Paulo, CartaCapital, São Paulo, 25 abr. 2014. Disponivel em: <https://www.cartacapital.com.br/sociedade/coronelpaulo-malhaes-temia-por-sua-vida-9839/>. Acesso em: 10 fev. 2020.
} 
levando-se em consideração seu peso, para que não viesse à tona. Era então jogado em um rio.

De acordo com o coronel, a Aeronáutica ofereceu a possibilidade de lançar corpos ao mar, mas o método foi recusado pelo $\mathrm{CIE}$, uma vez que a conduta propiciaria o compartilhamento de segredos. Malhães afirmou ainda que essa metodologia teria sido usada na "Operação Limpeza", empregada após o término da Guerrilha do Araguaia e no "Massacre de Medianeira" (CNV, 2014, p. 518-20).

A versão de Malhães não coincide inteiramente com o testemunho do analista de informações do DOI-Codi/SP, Marival Dias Chaves do Canto, que afirmou, em diversas ocasiões, que em São Paulo os corpos dos militantes eram "esquartejados" antes de serem lançados ao rio. Esses testemunhos, por sua vez, não coincidem com o do ex-delegado do DOPS/ES, Claudio Guerra. Segundo este policial, a partir de 1974, ele teria incinerado corpos de militantes assassinados na Casa da Morte. Por ordem do coronel Freddie Perdigão Pereira, do CIE, queimou esses corpos na usina Cambahyba, localizada em Campos de Goytacazes/RJ (CNV, 2014, p. 543-45).

A despeito dessas discrepâncias, a consolidação da estratégia de desaparecimento forçado tem origem na resolução estabelecida em reunião secreta, registrada pelo general Antônio Bandeira. ${ }^{43}$ Nesse momento, o responsável pelo combate à Guerrilha do Araguaia participou de um encontro com os generais Ernesto e Orlando Geisel, Milton Tavares e o presidente da República, Emílio G. Médici, cujo conteúdo foi registrado em ata. A reunião ocorreu em maio de 1973, quando foram discutidas as diretrizes da repressão política, cujo objetivo principal era "a utilização de todos os meios para eliminar, sem deixar vestígios, as guerrilhas rurais e urbanas, de qualquer jeito, a qualquer preço"44.

A reportagem na qual esse documento foi divulgado registrou ainda o depoimento de um general do setor de informações, que não quis se identificar. Ele contextualizou (e justificou) o momento em que foi tomada essa decisão com as seguintes palavras: "Em 1973, concluímos que ou a gente matava todo mundo ou essas guerrilhas nunca mais teriam fim". ${ }^{45}$

Nesse sentido, a investigação da CNV confirma a prevalência da centralização do aparato repressivo, bem como a adoção de uma política de desaparecimento forçado, sobretudo a partir de 1973. A Comissão estabeleceu a responsabilidade institucional das FFAA pelas graves violações de direitos humanos cometidas pelo Estado durante a ditadura militar. Com efeito, a CNV comprovou o protagonismo das FFAA na condução de crimes de tortura, execução sumária, desaparecimento forçado e ocultação de cadáveres, cujas diretrizes tinha origem nos gabinetes de presidentes e de ministros militares (CNV, 2014, p. 844-46). A Comissão evidenciou ainda o papel decisivo desempenhado pelo CIE e seus chefes da Seção de Operações na cooperação repressiva empreendida entre o Brasil e demais países do Cone

\footnotetext{
${ }^{43}$ Cf. documento encontrado na casa do general Bandeira, em 1997 (Teles, 2010, p. 262). A divulgação de seu "fac-símile" consolidaria os dados encontrados nas investigações mencionadas.

44 Destaques nossos. Ribeiro Jr., Amaury. A ordem é matar. IstoÉ, São Paulo, 24 mar. 2004a. Disponível em: <http:// comissaodaverdade.al.sp.gov.br/upload/030-materia-istoe-24-03-2002-a-ordem-e-matar.pdf>. Acesso em: 20 fev. 2020.

45 Cf. Ribeiro Jr. (2004a). Essa informação foi confirmada por Marival Chaves em depoimento à CNV.
} 
Sul. ${ }^{46}$

Pesquisas anteriores já indicavam o predomínio de um padrão de conduta nas relações entre o DOI-Codi/SP e o DOPS/SP, a partir do início do comando do major Brilhante Ustra, em setembro de 1970, conforme revelou Marcelo Godoy (2014, p. 192, 232, 253-78). A partir de então reduziram os conflitos e as disputas, com o estabelecimento de certo intercâmbio de homens e informações com o delegado Fleury e o DOPS/SP, tal como passou a ocorrer no "Sítio 31 de março", importante centro clandestino de tortura. ${ }^{47}$

Outro caso emblemático ilustra a prevalência da colaboração entre o DOI-Codi/ ClE e o DOPS/SP: o de Inês Etienne Romeu e dos demais prisioneiros sequestrados e levados para a "Casa da Morte". ${ }^{48}$ Agentes de outros organismos torturaram nesse local, entre outros, rompendo com a orientação dos manuais militares de manter a compartimentação das funções e a execução das operações. Os DOI-Codi eventualmente se sobrepunham a cargos e instituições no cumprimento de suas funções. No entanto, esta sobreposição de hierarquias era parte da lógica repressiva, na medida em que criava uma gama de órgãos e funções para dar lugar aos aliados e lidar com as disputas, ainda que centralizasse a decisão sobre a vida e a morte daqueles considerados "irrecuperáveis" pelo regime (Teles, 2011, p. 149-51).

De acordo com o agente Marival Chaves, a partir de fevereiro de 1973, o coronel Freddie Perdigão Pereira passou a atuar no DOI/SP, para estabelecer uma ligação mais orgânica entre este e a "Casa da Morte" (CNV, 2014, p. 541). Esta informação revela mais uma evidência da consolidação da estratégia de desaparecimento forçado. Com efeito, desde o desenvolvimento de uma vasta rede secreta de órgãos especiais de segurança interna articulada a centros clandestinos, controlada por serviços de informação (com a primazia do CIE), o aparato repressivo desempenhou funções de polícia política. Os centros clandestinos de extermínio passaram gradativamente a adotar a estratégia de desaparecimento de dirigentes, banidos, "cubanos" e militantes considerados "perigosos" (Teles, 2011, p. 88, 136, 149-52).

Em 1973, os órgãos de segurança interna se dedicaram ao extermínio dos guerrilheiros no Araguaia, de militantes remanescentes da guerrilha urbana, assim como de grupos contrários à luta armada. Os alvos preferenciais eram os dirigentes e militantes estratégicos da ALN e Molipo, mas também da AP-ML, PCB, bem como religiosos e membros do movimento estudantil e operário. Nesse mesmo ano, O DOI-Codi desfechou duros golpes contra O PCB, prendendo alguns de seus principais dirigentes. ${ }^{49}$

A partir de abril de 1974, porém, inicia-se o segmento da "Operação Radar", destinado

${ }^{46}$ Sobretudo o dos coronéis Carlos Alberto B. Ustra e José Antonio N. Belham, cf. CNV (2014, vol. I, p.224, 260). A CNV também menciona o ten.-cel. Carlos Sérgio Torres, chefe da S. de Operações do CIE, sem oferecer muitas informações a respeito de sua atuação, cf. CNV (2014, vol. III, p. 1685)

47 Centro controlado pelo capitão Ênio Pimentel, chefe da Seção de Investigações do DOI/SP (Teles, 2011; Godoy, 2014, p. 387400).

48 O caso do sindicalista Aluísio Palhano Pedreira Ferreira ilustra esse aspecto. Ele foi visto no DOI-Codi/SP por Altino Dantas, de onde teria sido retirado em 20/05/71. Palhano contou a ele que havia sido sequestrado na rua, em São Paulo, em 09/05/71. No dia seguinte foi levado ao Cenimar/RJ. O ex-preso político Nelson Rodrigues Filho o viu no DOI-Codi/RJ e Inês Etienne contou que Palhano teria sido levado para Petrópolis em 13/05/71 (Almeida et. al., 2009, p. 251-52). Em 2018, o Centro de Antropologia e Arqueologia Forense (CAAF/Unifesp) identificou seus restos mortais encontrados na Vala de Perus, em São Paulo (Diniz, 2018).

49 Entre 1971 e 1973, ao menos 6 militantes do PCB foram assassinados por órgãos de segurança interna (Almeida et al., 2009). Note-se que a "Operação Radar" teve início em março de 1973, com a finalidade de extinguir a ALN (Almeida et al., 2009, p. 424-431; Godoy, 2014, p. 359-385). 
a preparar uma grande ofensiva contra o PCB. Essa operação se estendeu para outros estados e resultou no desaparecimento de diversos dirigentes do Comitê Central do PCB. Além de destruir suas gráficas clandestinas, a repressão desmantelou diretórios do partido em diversos estados, em operações que prenderam centenas de pessoas. ${ }^{50}$

Parte considerável da "Operação Radar" foi comandada pelo coronel Aldir dos Santos Maciel, chefe do DOI/SP desde fevereiro de 1974. Um grupo de extermínio do CIE/ DOI prendeu e executou militantes do PCB sem deixar pistas. Os assassinatos ocorreram em casas ou chácaras clandestinas, o que facilitou a ocultação dos cadáveres. A localização e a prisão de dirigentes eram feitas, em larga medida, por intermédio da infiltração de militantes, os quais aceitavam a tarefa mediante remuneração ou não. O desaparecimento de dirigentes e militantes tinha por objetivo, além de proteger os nomes dos "infiltrados", ocultar os crimes cometidos pelo aparato repressivo, evitando atritos com as oposições e o desgaste político, no Brasil e no exterior. ${ }^{51}$

Conforme mencionado antes, a 'imagem do Brasil' sempre foi um tema relevante para os militares, tanto para se diferenciarem das demais ditaduras latino-americanas quanto para estabelecer um arcabouço legal que sustentasse o regime, na ausência de legitimidade. Ademais, a prática do desaparecimento favorecia a impunidade dos agentes repressivos envolvidos (Padrós, 2005, p. 645-46), a qual aumentava a sensação de impotência e paralisia dos familiares e do entorno social das vítimas, ampliando os efeitos do terror e a sua persistência no tempo. Desse modo, ao longo do ano de 1973 verificou-se um significativo aumento na quantidade de desaparecidos políticos. Em contrapartida, durante 1974, ano da posse de Ernesto Geisel na presidência da República, 54 militantes desapareceram, enquanto apenas dois foram considerados "mortos oficiais". 52

A relevância do documento e dos testemunhos mencionados acima é inegável, sobretudo após a divulgação, em maio de 2018, do memorando secreto da CIA, dirigido ao Secretário de Estado dos EUA, Henry Kissinger. ${ }^{53}$ No documento, o então diretor da CIA, William E. Colby, ${ }^{54}$ relata um encontro realizado em 30 de março de 1974, no qual estavam presentes Ernesto Geisel, João Batista Figueiredo (então chefe do Serviço Nacional de Informações) e os generais Milton Tavares de Souza (comandante do CIE) e Confúcio Danton de Paula Avelino,

\footnotetext{
${ }^{50}$ A operação resultou no desaparecimento de 21 membros do PCB, sendo 11 membros do Comitê Central e a prisão de ao menos de 679 pessoas (Almeida et al., 2009).

${ }^{51}$ A adoção do desaparecimento forçado na América Latina coincide com o uso desta estratégia repressiva no Vietnã por parte dos EUA (Riquelme, 1993, p. 35). No Brasil, os primeiros desaparecimentos ocorreram em 1964, quando ao menos 5 militantes desapareceram sem deixar vestígios (Almeida et al., 2009, p. 86-90).

52 Não estão computados aqui os camponeses e indígenas, entre outros movimentos sociais, tais como as vítimas da repressão ao movimento negro etc.

53 Documento encontrado por Matias Spektor. Disponivel em: <https://twitter.com/MatiasSpektor/status/994587769220591617> Acesso em: 15 maio 2018.

54 Colby coordenou o Programa Phoenix no Vietnã do Sul, em 1967, cuja estrutura teria inspirado a OBAN (Huggins, 1998, p. 176-77). O programa tinha por objetivo identificar, isolar e eliminar os vietcongs do Vietnã do Sul por meio de centros de coordenação da inteligência, sob supervisão direta da CIA, financiados pelo tráfico de drogas. Consistiu no estabelecimento de ações de investigação, sequestro e tortura para obter delações e cooptar militantes para atuarem como agentes duplos, identificando e apontando lideranças para que fossem eliminadas (Valentine, 2017). Colby foi obrigado a pedir demissão da direção da CIA, após o escândalo de Watergate em 1974.
} 
seu substituto no comando do $\mathrm{CIE} .{ }^{55}$

De acordo com o memorando, o general Milton Tavares afirmou que o país não poderia ignorar a "ameaça terrorista e subversiva", e que os métodos "extralegais deveriam continuar a ser empregados contra subversivos perigosos". Segundo Colby, o general Figueiredo apoiou a estratégia e defendeu sua continuidade. Ernesto Geisel, então, pediu tempo para pensar. No dia 1․ de abril, ele e Figueiredo decidiram seguir com essas operações, salientando que apenas "os subversivos perigosos" deveriam ser executados. Contudo, Geisel assinalou que Figueiredo seria o responsável pela autorização de executar dissidentes, mediante consulta ao chefe do CIE.

Em conversa realizada em janeiro de 1974, envolvendo o general Ernesto Geisel, o recém-empossado presidente revela o conhecimento e sua aprovação à adoção da estratégia de desaparecimento forçado. Antes da reunião com o diretor da CIA, Geisel defendeu a manutenção do desaparecimento de prisioneiros políticos, desde que sem vestígios. Em conversa com o tenente-coronel Germano Arnoldi Pedrozo, chefe do serviço de segurança da Presidência, Geisel perguntou:

'- Pegaram alguns?'

- 'Pegamos. Foram pegos quatro argentinos e três chilenos', respondeu Pedrozo.

'- E não liquidaram, não?'

- 'Ah, já, há muito tempo. É o problema, não é? Tem elemento que não adianta deixar vivo, aprontando. Infelizmente, é o tipo da guerra suja em que, se não se lutar com as mesmas armas deles, se perde. Eles não têm o mínimo escrúpulo.

'- É, o que tem que fazer é que tem que nessa hora agir com muita inteligência para não ficar vestígio nessa coisa'. ${ }^{56}$

Os documentos, bem como os depoimentos de militares previamente mencionados, não deixam margem para dúvidas. Eles confirmam a participação direta da cúpula das FFAA e do Estado de Segurança Nacional nas decisões referentes à eliminação de militantes "perigosos". Documentam o momento em que os dirigentes do país optaram por uma política de desaparecimento seletivo de dissidentes. Os documentos, assim como a investigação da CNV (não obstante suas insuficiências e a falta de colaboração das FFAA), corroboram pesquisas anteriores, que evidenciavam a atuação centralizada dos militares, articulada por meio de cooperação dos organismos de segurança interna, sob comando do Exército.

O memorando da CIA revela a prevalência da "união na desunião" característica do estado de exceção instaurado em 1964, não obstante os atritos e disputas internas pelo poder. O documento desfecha um duro golpe sobre a "visão dualista" dos militares, que os classifica segundo a dicotomia entre "duros" e "moderados", sugerindo a existência de mais paralelos do

\footnotetext{
55 Cf. site do Departamento de Estado dos EUA. Disponivel desde 2015 em: <https://history.state.gov/historicaldocuments/ frus1969-76ve11p2/d99?platform=hootsuite>. Acesso em: 15 maio 2018

${ }^{56}$ Conversa de 18/01/74. APGCS/HF apud Gaspari (2002, p.387). Destaques nossos.
} 
que distinções entre os governos Médici e Geisel, ${ }^{57}$ no que concerne às estratégias repressivas, sobretudo no que tange ao desaparecimento forçado. As evidências analisadas sugerem que as FFAA apresentaram unidade no plano estratégico, situando suas tensões e divergências no campo das opções táticas.

O exame dessas evidências ilumina os meandros e as nuances do complexo panorama militar, consolidando aspectos que amparam nossa argumentação acerca da centralização dos mecanismos de decisão do aparato repressivo e da prevalência do respeito à hierarquia nos governos militares. Tais indícios reforçam a hipótese de que não é possível classificar os "castelistas" como um grupo "liberal" e "moderado", características da autoimagem difundida no período de consolidação da "candidatura" de Geisel à presidência (Teles, 2005, p. 74-77; Martins Filho, 1995, p. 40-41, 95-99, 113-122).

A derrota do governo nas eleições de 1974 exigiu novas adaptações relativas às estratégias repressivas. Nos anos seguintes, os militares continuaram a utilizar a estratégia do desaparecimento forçado, sobretudo no âmbito da Operação Condor, ao lado da prática de assassinatos divulgados com falsas versões da morte. O regime recorreu com ênfase à repressão de camponeses e trabalhadores rurais, entre outros grupos sociais, cujas mortes ocorriam em regiões distantes da atenção da opinião pública. ${ }^{58}$ As torturas, porém, prosseguiram, ${ }^{59}$ repercutindo negativamente sobre a imagem do governo. O Estado de Segurança Nacional lentamente reduz o escopo de sua aplicação. Por outro lado, a repercussão das lutas dos familiares de vítimas fatais da ditadura, levou os órgãos de segurança interna a assassinarem em 1976 a estilista Zuzu Angel, a combativa mãe de um desaparecido político - Stuart Edgard Angel Jones (Almeida et al., 2009, p. 649-651) -, o que gerou nova onda de medo e indignação.

Com a derrota da guerrilha e os duros golpes desfechados sobre os partidos clandestinos de esquerda, por um lado, e a vitória do MDB nas eleições de 1974, de outro, a resistência à ditadura se traduz na atuação política no partido da oposição consentida, em entidades e movimentos sociais legais. Gradualmente, a violência estatal também se dirige à cena pública, tal como se verificou na repressão às manifestações estudantis e no fechamento do Congresso Nacional em 1977, além dos assassinatos de camponeses, indígenas e favelados conduzidos ao arrepio da lei. Ameaças e, eventualmente, atentados traduziram a insegurança e a contrariedade de setores envolvidos diretamente no aparato repressivo, sem chegar a se configurar em autonomia política.

Com efeito, evidências encontradas em um relatório de inteligência enviado ao Departamento de Estado norte-americano sobre o caso Riocentro, divulgado em 2018, parecem corroborar os indícios revelados pelo MPF: ${ }^{60}$ a cúpula do SNI e do Exército sabia e aprovava a

${ }^{57}$ Com efeito, Geisel afirmou que "Médici, ao longo da vida, sempre esteve ligado mais ou menos a nós", cf. D'Araújo e Castro (1997, p. 433).

58 SECRETARIA dos Direitos Humanos. Camponeses mortos e desaparecidos: excluídos da justiça de transição. Brasília/DF: Secretaria de Estado de Direitos Humanos, 2013. 225 p.

${ }^{59}$ ARQUIDIOCESE de São Paulo. Perfil dos atingidos. Petrópolis/RJ: Vozes, 1987. Projeto Brasil: Nunca mais, vol. 3. 311 p.

60 Segundo o MPF, os denunciados no caso planejaram o ataque desde um ano antes do dia do show do Dia do Trabalhador, em 1981, e contaram com um núcleo de planejamento e outro, de cunho operacional (denominado "Grupo Secreto"). O tenentecoronel Freddie Perdigão Pereira, do CIE, era o elo entre os 2 núcleos e entre estes e os altos escalões das FFAA. Disponível em: http://www.mpf.mp.br/ri/sala-de-imprensa/noticias-ri/mpf-ri-denuncia-seis-por-atentado-a-bomba-no-riocentro-ocorridoem-1981. Acesso em: 18/02/2015. 
organização do atentado pelo DOI-Codi. Segundo o documento, o objetivo era responsabilizar as esquerdas pelo ato terrorista e, assim, retardar a abertura política. $O$ "terrorismo militar" estava inserido em um contexto de intimidação da sociedade e de neutralização dos oposicionistas com atuação legal. Nesse sentido, esse relatório revela essa mudança de rumos na estratégia repressiva, algo que se verificava pelo menos desde 1976, ${ }^{61}$ bem como a manutenção da centralização na condução dos órgãos de segurança interna. ${ }^{62}$ Note-se que a estrutura do sistema DOI-Codi foi mantida, sem modificações relevantes, até o ano de 1991 (Godoy, 2014, p. 522-25).

É possível afirmar que o desaparecimento forçado elide a apuração dos fatos, e a justiça, assim como o silêncio e o esquecimento, favorecem acomodações políticas. Por outro lado, o desaparecimento é uma ferida (trauma) aberta que impossibilita o trabalho de luto, gerando angústia e incertezas. Impulsionados por essa experiência-limite e encorajados pelas sucessivas derrotas eleitorais do governo, os familiares de desaparecidos e deputados "Autênticos" do MDB organizaram uma campanha favorável à criação de uma CPI sobre os Direitos Humanos, entre 1975 e $1979 .{ }^{63}$ Ao denunciarem os desaparecimentos e demandarem a apuração desses crimes, obtiveram certo apoio e grande repercussão na imprensa. Essas pressões resultaram na "crise dos desaparecidos" de 1975 que, ao colocarem no centro do debate público a defesa dos direitos humanos, contraditaram a distensão política, produzindo mais desgaste político ao governo.

\section{Considerações finais}

Os documentos e testemunhos analisados aqui corroboram as análises que consideram a atuação centralizada dos militares, articulada por meio da cooperação dos organismos de segurança interna, sob o comando do Exército. Revelam a predomínio da "união na desunião" característica do Estado de Segurança Nacional instaurado em 1964, no que diz respeito à repressão política ao longo do período estudado. Essas evidências contrastam com a "visão dualista" sobre os militares, que os classificava a partir da dicotomia entre "duros" e "moderados". Tal como revelado no texto, as FFAA apresentaram notável unidade no plano estratégico, situando suas tensões e divergências no campo das opções táticas.

O texto aborda a complexidade do panorama político-institucional do início dos anos 1970, sugerindo a existência de mais paralelos do que distinções entre os governos dos generais Médici e Geisel, no que diz respeito às estratégias repressivas, sobretudo quanto ao desaparecimento forçado. O exame das evidências disponíveis reforça a hipótese de que

${ }^{61}$ Vejam-se os atos terroristas de militares, tais como o sequestro do Bispo de Volta Redonda, D. Adriano Hypólito, ou a explosão de bombas no Cebrap e no Jornal Opinião, entre outros, para os quais não há provas definitivas de que tenham sido promovidos pelos mesmos autores do atentado do Riocentro. Deve-se observar, contudo, que os indícios sugerem o mesmo padrão de atuação.

62 Cf. "Riocentro: um mês após bomba, EUA já consideravam ataque de militares". G1, Jornal Nacional, 21/05/2018. O relatório, de 29/05/1981, foi encontrado no Arquivo Nacional e é parte dos 715 documentos liberados pelo governo Obama para a CNV, enviados ao arquivo em 2015. Disponivel em: http://g1.globo.com/jornal-nacional/noticia/2018/05/riocentro-um-mes-aposbomba-eua-ja-consideravam-ataque-de-militares.html. Acesso em: 29/03/2020.

63 A proposta de criação de uma CPI de 1975 foi retomada em 1979, mas, novamente, manobras regimentais impediram que a CPI fosse constituída (Teles, 2005, p. 192-196). 
os "castelistas" não podem ser classificados como "moderados", autoimagem difundida no período de consolidação da "candidatura" de Ernesto Geisel à presidência.

Nesse sentido, buscou-se demonstrar aqui como o desaparecimento forçado desempenhou papel central na eclosão da distensão política, a fim de evitar o desgaste político do governo quanto à divulgação de denúncias de violações aos direitos humanos, em um contexto no qual emergem os primeiros sinais de esgotamento do "milagre econômico". O desaparecimento de dissidentes viria a auxiliar na promoção e difusão da imagem de "moderado" de Geisel e o grupo "castelista", facilitando o diálogo com as "elites responsáveis" a respeito do projeto de descompressão política.

Os ecos traumáticos da ditadura militar desempenharam um papel central no desenho institucional da transição democrática, assim como na avaliação do legado autoritário deixado no Brasil. O desaparecimento forçado, caracterizado como crime permanente e de lesa a humanidade, tornou-se um dos eixos centrais das demandas por "verdade e justiça" no país e na América Latina. Nesse sentido, a condenação do Brasil na OEA em 2010, no caso referente à Guerrilha do Araguaia é emblemática. A decisão da Corte Interamericana de Direitos Humanos coloca em xeque a transição democrática, desacreditando o mito do acordo fundador da Nova República, supostamente celebrado pela Lei de Anistia (Bernardi, 2015).

O caso Araguaia influenciou decisivamente a formulação da Lei de Informação e a criação da Comissão da Verdade, impulsionando o debate público a respeito do legado ditatorial no país. Os limites impostos à CNV e o não cumprimento da sentença da OEA em seus aspectos mais importantes - a promoção de investigações efetivas relativas aos mortos e desaparecidos e a consecução da justiça -, contribuíram para o aprofundamento das contradições da precária democracia brasileira. Diante dos retrocessos políticos e sociais observados no país, o legado da ditadura militar se interpõe com força no Brasil, assim como a reflexão e a elaboração social sobre o passado recente.

\section{Referências bibliográficas}

AGAMBEN, Giorgio. Estado de exceção. São Paulo: Boitempo, 2004a. 144 p.

AGAMBEN, Giorgio. Homo Sacer: O poder soberano e a vida nua I. Belo Horizonte: UFMG, 2004b. 197 p.

ALMEIDA, Criméia Alice Schmidt de; TELES, Janaína de Almeida; TELES, Maria Amélia de A.; LISBÔA, Suzana K. (Orgs.). Dossiê Ditadura: os mortos e desaparecidos políticos no Brasil (1964-1985). 2o Ed. São Paulo: Imprensa Oficial do Estado de São Paulo, 2009. 772 p.

ALVES, José Augusto Lindgren. Os direitos humanos como tema global. São Paulo: Perspectiva, 1994. 264 p.

ALVES, Maria Helena Moreira. Estado e oposição no Brasil (1964-1984). Petrópolis: Vozes, 1984. $424 \mathrm{p}$. 
AZEVEDO, Débora Bithiah de; RABAT, Márcio Nuno. Parlamento Mutilado: Deputados federais cassados pela ditadura de 1964. Brasília: Edições Câmara, 2012. 236 p.

BENEVIDES, Maria Victória. Fé na Luta - A Comissão Justiça e Paz de São Paulo, da ditadura à democratização. São Paulo: Lettera.doc, 2008. 424 p.

BERNARDI, Bruno Boti. O sistema interamericano de direitos humanos e justiça de transição: impactos no Brasil, Peru, Colômbia e México. 2015. Tese (Doutorado em Ciência Política) Faculdade de Filosofia, Letras e Ciências Humanas, Universidade de São Paulo, São Paulo, 2015. 2 v. $952 \mathrm{f}$.

BERNARDI, Bruno Boti. Silence, hindrances, and omissions: The Inter-American Commission on Human Rights and the Brazilian military dictatorship. The International Journal of Human Rights, on-line, v. 22, n. 9, p. 1123-1143, 2018. http://doi.org/10.1080/13642987.2017.1299915.

BIOCCA, Ettore. Estratégia do Terror: A face oculta e repressiva do Brasil. Lisboa: Iniciativas Editoriais, 1974. 353 p.

BRESSER PEREIRA, Luiz C. As contradições da inflação brasileira. Encontros com a Civilização Brasileira, Rio de Janeiro, n. 21, s. p., mar. 1980.

CALVEIRO, Pilar. Poder e desaparecimento: os campos de concentração na Argentina. São Paulo: Boitempo, 2013. 210 p.

CODATO, Adriano N. Uma história política da transição brasileira: da ditadura militar à democracia. Revista de Sociologia e Política, Curitiba, n. 25, p. 83-106, 2005. http://doi.org/10.1590/S010444782005000200008 .

COMBLIN, Joseph. A ideologia da segurança nacional: O poder militar na América Latina. Rio de Janeiro: Civilização Brasileira, 1978. 251 p.

COUTO E SILVA, Golbery do. "Sístoles e Diástoles". In: Geopolítica e Poder. Rio de Janeiro, Ed. UniverCidade, 2003, p.475-500. 633 p.

D'ARAÚJO, Maria Celina et al. (org.). Os Anos de Chumbo: a memória militar sobre a repressão. Rio de Janeiro: Relume Dumará, 1994a. 336 p.

D'ARAÚJO, Maria Celina et al. (org.). Visões do golpe: 12 depoimentos de oficiais que articularam o golpe militar de 1964. Rio de Janeiro: Relume Dumará, 1994b. 240 p.

DINIZ, Mariana. Ossada de sindicalista morto pela ditadura é identificada após 47 anos. Agência Brasil, on-line, 3 dez. 2018.

DÓRIA, Palmério et al. A guerrilha do Araguaia. São Paulo: Alfa-Ômega,1978. Série História Imediata 1. $78 \mathrm{p}$.

DUARTE, Celina Rabello. Imprensa e redemocratização no Brasil: um estudo de duas conjunturas, 1945 e 1974-78. 1987. Dissertação (Mestrado em Ciências Sociais) - Pontifícia Universidade Católica de São Paulo, São Paulo, 1987. 352 f.

FICO, Carlos. Reinventando o otimismo: ditadura, propaganda e imaginário social no Brasil. Rio de Janeiro: FGV, 1997. 188 p. 
FICO, Carlos. Como eles agiam: os subterrâneos da ditadura militar. Rio de Janeiro: Record, 2001. $269 \mathrm{p}$.

FICO, Carlos. Além do golpe: versões e controvérsias sobre 1964 e a ditadura militar. Rio de Janeiro: Record, 2004. 391 p.

FON, Antonio Carlos. Tortura: a história da repressão política no Brasil. São Paulo: Global, 1979. $79 \mathrm{p}$.

GASPARI, Elio; HOLLANDA, Heloisa Buarque de; VENTURA, Zuenir. 70/80 Cultura em trânsito. Da repressão à abertura. Rio de Janeiro: Aeroplano, 2000. 336 p.

GODOY, Marcelo. A Casa da Vovó. Uma biografia do DOI-CODI (1969-1991), o centro de sequestro, tortura e morte da ditadura militar. São Paulo: Alameda, 2014. 612 p.

GREEN, James N. Apesar de vocês: oposição à ditadura brasileira nos Estados Unidos (19641985). São Paulo: Companhia das Letras, 2009. 560 p.

HAYNER, Priscilla. Verdades Silenciadas: la Justicia Transicional y el reto de las Comisiones de la Verdad. Madrid: Bellaterra, 2014. 558 p.

HOEVELER, Rejane Carolina. Ditadura e democracia restrita: a elaboração do projeto de descompressão controlada no Brasil (1972-1973). Monografia de conclusão de curso (Bacharelado em História) - Universidade Federal do Rio de Janeiro, 2012. 99 f.

HUGGINS, Martha K. Polícia e Política: relações Estados Unidos/América Latina. São Paulo: Cortez, 1998. 328 p.

HUNTINGTON, Samuel. Political Order in Changing Societies. New Haven: Harvard Press, 1968. $488 \mathrm{p}$.

JOFFILY, Mariana. No centro da engrenagem: Os interrogatórios na Operação Bandeirante e no DOI de São Paulo (1969-1975). Rio de Janeiro: Arquivo Nacional, 2008. 352 p.

JUDT, Tony. Pós-Guerra: uma história da Europa desde 1945. Rio de Janeiro: Objetiva, 2008. $880 \mathrm{p}$.

JUDT, Tony. O século XX esquecido: Lugares e memórias. Lisboa: Edições 70, 2017. 462 p.

KUCINSKI, Bernardo. A síndrome da antena parabólica: ética no jornalismo brasileiro. São Paulo: Fundação Perseu Abramo, 1998. 198 p.

LEMOS, Renato Luís do Couto Neto e. A conexão Harvard e a Política de Descompressão: sobre as origens da Transição Política no Brasil pós-64. Estudos Históricos, Marechal Cândido Rondon, v. 18, n. 2, p. 559-590, 2014.

MACARINI, José Pedro. A política econômica do governo Médici. Nova Economia, Belo Horizonte, v. 15, n. 3, p. 53-92, set./dez. 2005. http://doi.org/10.1590/S0103-63512005000300003.

MARTINS FILHO, João Roberto. Tortura e Ideologia: os militares brasileiros e a doutrina de guerre révolutionnaire (1959-1974). In: SANTOS, Cecília Macdowell; TELES, Edson; TELES, Janaína de Almeida (Org.). Desarquivando a ditadura: memória e justiça no Brasil. São Paulo: 
Hucitec, 2009. V. 1. 2009. 340 p.

MARTINS FILHO, João Roberto. Segredos de Estado: O governo britânico e a tortura no Brasil (1969-1976). 2a . ed. Salvador: Saga Editora, 2019. 370 p.

MARTINS FILHO, João Roberto. Tortura e Ideologia: os militares brasileiros e a doutrina de guerre révolutionnaire (1959-1974). In: SANTOS, Cecília Macdowell; TELES, Edson; TELES, Janaína de Almeida (org.). Desarquivando a ditadura: memória e justiça no Brasil. São Paulo: Hucitec, 2009. V. 1. 2009. p. 182-186.

MATHIAS, Suzeley Kalil. Distensão no Brasil: O projeto militar (1973-1979). Campinas/SP: Papirus, 1995. $158 \mathrm{p}$.

NAPOLITANO, Marcos. 1964: história do regime militar brasileiro. São Paulo: Contexto, 2014. $428 \mathrm{p}$.

PADRÓS, Enrique Serra. Como el Uruguay no hay... Terror de Estado e Segurança Nacional. Uruguai (1968-1985): do Pachecato à Ditadura Civil-Militar. Tese (Doutorado em História). Universidade Federal do Rio Grande do Sul, Porto Alegre, 2005. 876 f.

PRADO, Luiz Carlos D.; EARP, Fábio S. O 'milagre' brasileiro: crescimento acelerado, integração internacional e concentração de renda (1967-1973). In: FERREIRA, Jorge; DELGADO, Lucilia de A. N. (org.). O Brasil Republicano. O tempo da ditadura: regime militar e movimentos sociais em fins do século XX. Vol. 4, Rio de Janeiro: Civilização Brasileira, 2003. p. 208-241.

QUINALHA, Renan Honório. Justiça de Transição: contornos do conceito. São Paulo: Expressão Popular, 2013. 252 p.

QUINALHA, Renan Honório; TELES, Edson L. de A. (org.). Espectros da Ditadura: da Comissão da Verdade ao bolsonarismo. São Paulo: Autonomia Literária, 2020. 484 p.

RIQUELME U., Horacio. América do Sul: direitos humanos e saúde psicossocial. In: RIQUELME U., Horacio (ed.). Era De Névoas: Direitos Humanos, Terrorismo de Estado e Saúde Psicossocial na América Latina. Caxias do Sul, EDUCS, 1993. 216 p.

ROBIN, Marie-Monique. Escuadrones de la Muerte: La Escuela Francesa. Buenos Aires: Editorial Sudamerica, 2004. 540 p.

SÁ MOTTA, Rodrigo Patto. As universidades e o regime militar: Cultura política brasileira e modernização autoritária. Rio de Janeiro: Zahar, 2014. 448 p.

SANTOS, Cecília M. A Justiça a serviço da memória: mobilização jurídica transnacional, direitos humanos e memória da ditadura. In: SANTOS, Cecília MacDowell; TELES, Edson; TELES, Janaína de Almeida. (org.). Desarquivando a Ditadura: Memória e Justiça no Brasil. São Paulo: Hucitec, 2009. p. 472-495. v. 2.

SANTOS, Wanderley Guilherme dos. Estratégias de descompressão política. In: SANTOS, Wanderley Guilherme dos. Poder \& Política: crônica do autoritarismo brasileiro. Rio de Janeiro: Forense Universitária, 1978. p. 143-211.

SELIGMANN-SILVA, Márcio. A história como trauma. In: NESTROVSKI, Arthur; SELIGMANNSILVA, Márcio (org.). Catástrofe e Representação. São Paulo: Escuta, 2000. p. 73-98. 
SERBIN, Kenneth P. Diálogos na Sombra: Bispos e Militares, Tortura e Justiça Social na Ditadura. São Paulo: Cia. das Letras, 2001. 576 p.

SINGER, Paul. A crise do "milagre". Interpretação crítica da economia brasileira. 4a ed. Rio de Janeiro: Paz e Terra, 1977. 168 p.

SINGER, Paul. O processo econômico. In: AARÃO REIS, D. (coord.). Modernização, ditadura e democracia (1964-2010). Rio de Janeiro: Objetiva, 2014. p. 183-231.

SINGER, Paul. Repartição da renda. Pobres e Ricos sob o regime militar. 2ª . ed. Rio de Janeiro: Zahar, 1986. 95 p.

SKIDMORE, Thomas. Brasil de Castelo a Tancredo. Rio de Janeiro: Paz e Terra, 1988. 608 p.

TEIXEIRA, Alessandra. Construir a delinquência, articular a criminalidade: Um estudo sobre a gestão dos ilegalismos na cidade de São Paulo. 2012. Tese (Doutorado em Sociologia) Faculdade de Filosofia, Letras e Ciências Humanas, Universidade de São Paulo, São Paulo, 2012. $352 \mathrm{f}$.

TELES, Janaina de Almeida. Os herdeiros da memória: as lutas e as memórias dos familiares de mortos e desaparecidos por "verdade e justiça" no Brasil. Dissertação (Mestrado em História) - Faculdade de Filosofia, Letras e Ciências Humanas, Universidade de São Paulo, São Paulo, 2005. $376 \mathrm{f}$.

TELES, Janaina de Almeida. Os familiares de mortos e desaparecidos políticos e a luta por 'verdade e justiça' no Brasil. In: TELES, Edson; SAFATLE, Vladimir (org.). O que resta da ditadura: A exceção brasileira. São Paulo: Boitempo, 2010. p. 253-298.

TELES, Janaina de Almeida. Memórias dos Cárceres da Ditadura: as lutas e testemunhos dos presos políticos no Brasil. 2011. Tese (Doutorado em História) - Faculdade de Filosofia, Letras e Ciências Humanas, Universidade de São Paulo, São Paulo, 2011. 519 f.

TELES, Janaina de Almeida. Apresentação - Ditadura e repressão no Brasil e na Argentina: paralelos e distinções. In: CALVEIRO, Pilar. Poder e desaparecimento: os campos de concentração na Argentina. São Paulo: Boitempo, 2013. p. 07-18.

TOSI, Giuseppe; FERREIRA, Lúcia de Fátima Guerra. (org.). Brasil, violação dos direitos humanos: Tribunal Russel II. João Pessoa: Ed. UFPB, 2014. 346 p.

VALENTINE, Douglas. The CIA as Organized Crime: How Illegal Operations Corrupt America and the World. Atlanta, GA: Clarity Press, 2017. 448 p.

WESTHROP Amy Jo et al. (org.). As Recomendações da Comissão Nacional da Verdade: Balanços sobre a sua implementação dois anos depois. Rio de Janeiro: ISER, 2016. 246 p.

Recebido em: 11 de maio de 2020

Aprovado em: 16 de outubro de 2020 